\title{
Türkiye'de Siyasi Partiler Arası Seçim İttifaklarına Yönelik Seçmen Algısı: Karaman ilinde Bir Araştırma
}

\author{
Perceptions of Voters For Election Alliance Between The Political Parties in Turkey: A \\ Research in Karaman Province
}

\section{Dr. Öğr. Üyesi Fadime DiLBER ${ }^{1}$ - Doç. Dr. Sefa USTA}

Başvuru Tarihi: 25.12.2019

Kabul Tarihi: 04.03.2020

Makale Türü: Araştırma Makalesi

Öz

Kuvvetler ayrılı̆̆ prensibi doğrultusunda, hükümet sistemleri içerisinde parlamenter, yarı başkanlık ve başkanlık sistemleri ön plana çıkmaktadır. Türkiye'de 2018 yılına kadar parlamenter sistem hüküm sürerken, 16 Nisan 2017 tarihinde gerçekleştirilen referandumla anayasa değişikliğine gidilmiş ve Cumhurbaşkanlığı Hükümet Sisteminin anayasal dayanağı oluşturulmuştur. 24 Haziran 2018 tarihinde yapılan seçimlerle birlikte Cumhurbaşkanliğı Hükümet Sistemine geçilmiştir. Bu seçimlerde, Cumhurbaşkanlığı Hükümet Sisteminin bir sonucu olarak siyasi partiler arası ittifak uygulamasına gidilmiştir. Buradan hareketle hazırlanan çalışmanın temel iddiası "Türkiye'de Cumhurbaşkanliğı Hükümet Sistemi'ne geçiş ve seçim sistemi sebebiyle siyasi partiler arasında ittifak yapılmasının zorunlu hale geldiğidir". Bu minvalden hareketle hazırlanan çalışmanın temel amacı, Karaman ili örneğinden hareketle, Türkiye'de siyasi partiler arası ittifak yapılmasının seçmenler üzerindeki etkisinin irdelenmesidir. Bu amaç doğrultusunda hazırlanan çalışmada ilk olarak Türkiye'de Cumhurbaşkanliğ Hükümet Sistemi hakkında genel hatlarıla bilgi verilmekte, Türkiye'de siyasi partiler arası ittifakın arka planı ele alınıp, 2018 genel seçim sonuçları incelenmektedir. Son olarak, seçmenlerin siyasi partiler arası ittifaka yönelik algılarını belirlemeye yönelik Karaman il merkezinde gerçekleştirilen alan araştırması sonucunda elde edilen bilgi ve bulgular değerlendirmeye tabi tutulmaktadır. Betimsel araştırma yöntemi ve nicel araştırma yöntemlerinden birisi olan anket tekniğinden yararlanılan çalışmada elde edilen bulgular ve sonuçlardan ilki, katılımcıların yarısı partiler arası ittifak hakkında net bilgiyi sahip olduğudur. Partiler arası ittifak yapılmasının oy verme davranışlarını değiştirmediğini belirtenlerin oranı \% 33'dür. Katılımcıların yarısı, seçim sistemi sebebiyle, siyasi partilerin tek başına iktidar olamayacağını düşünmeleri sebebiyle ittifaka yöneldiğini ifade etmiştir. Çalışmada elde edilen bir diğer bulgu, yazılı ve görsel medyanın ittifak içinde olan partilerin söylem, aday ve projelerini tanıtmada etkili olduğudur.

Anahtar Kelimeler: Cumhurbaşkanlığı Hükümet Sistemi, Seçim Sistemleri, Siyasi Partiler, Seçim İttifakı, Seçmen Davranışı

\footnotetext{
${ }^{1}$ Karamanoğlu Mehmetbey Üniversitesi, Sosyal Bilimler MYO, Sosyal Güvenlik Programı, fdilber@kmu.edu.tr, ORCID: 0000000209352593

${ }^{2}$ Karamanoğlu Mehmetbey Üniversitesi, İIBF, Siyaset Bilimi ve Kamu Yönetimi Bölümü, sefausta@kmu.edu.tr, ORCID: 0000000338467987
} 


\section{Abstract}

In line with the principle of separation of powers, parliamentary, semi-presidential and presidential systems stand out in the government systems. The presence of a parliamentary system in Turkey until 2018, with the plebiscite on April 16, 2017 changes were made to the constitution and the constitutional basis of the Presidential System of Government was established. With the elections held on June 24, 2018, the Presidential Government System was adopted. In these elections, as a result of the Presidential Government System, alliance between political parties was implemented. Thus, prepared basic argument of the work "due to the transition and the electoral system of presidential government system become mandatory in Turkey is making alliances between political parties". The main objective of the study prepared in light of this context, the example of Karaman province, is to examine the impact on voters of political parties from the alliance made in Turkey. Firstly, in this study, prepared for this purpose are informed in general terms about the Presidential System of Government in Turkey, the alliance between political parties by considering the background of the general election results in 2018 in Turkey is examined. Finally, the information and findings obtained from the field research conducted in Karaman province center to determine the perceptions of voters towards alliance between political parties are evaluated. The first of the findings and results obtained from the survey technique, which is one of the descriptive research methods and one of the quantitative research methods, is that half of the participants have clear information about the inter-party alliance. The rate of people who stated that alliance between parties did not change their voting behavior is 33\%. Half of the respondents stated that because of the electoral system, political parties turned to alliance because they thought that they could not be ruling alone. Another finding obtained from the study is that written and visual media are effective in introducing discourse, candidates and projects of the parties in alliance.

Keywords: Presidential Government System, Election Systems, Political Parties, Election Alliance, Voter Behavior

\section{Giriş}

Kuvvetler birliği ve kuvvetler ayrılığına dayalı olmak üzere hükümet sistemleri kendi içerisinde ikili bir ayrıma tabi tutulmaktadır. Kuvvetler birliğine dayalı hükümet sistemleri içerisinde, monarşi, tiranlık, diktatörlük gibi tek kişinin yönetimi; oligarşi ve aristokrasi gibi bir grubun yönetimi şeklinde ortaya çıkmaktadır.

İktidara gelen devlet başkanının halkın kullandığı oylar vasıtasıyla gerçekleştirilen seçim dışı bir yolla iş başına geldiği ve bir kişi tarafından ırsi yönetim olarak biçimi olarak ifade edilen monarşi yönetimleri mutlak ve meşruti olmak üzere ikiye ayrılmaktadır. Mutlak monarşi anlayışında, iktidarı elinde tutan monarkın hak ve yetkilerinin hiçbir organ veya kurum tarafından sınırlandırılmaması söz konusu olmaktadır. Meşruti monarşide ise, iktidara sahip olan monarkın elindeki yetkiler yasal bir sınırlama çerçevesinde kullanılabilmektedir. Meşruti monarşi de hükümdarın yanında, onunla beraber iktidarı paylaşan ve halkın seçmiş olduğu temsilcilerden oluşan parlamento da bulunmaktadır (Gözler, 2016, s. 52-53). Diktatörlük ise 
yasama, yürütme ve yargı erklerinin tek bir kişi veya kişilerde toplandığı, zorlayıcı, katı ve sert bir rejim hüküm sürdüğü yönetim biçimidir. Totaliter ve otoriter diktatörlükler şeklinde ayrımın yapıldığı diktatörlügün egemen olduğu hükümet sistemlerinde rejimin tek sahibi iktidarı elinde tutan bir şahıs veya bir gruptur (Gözler, 2016, s. 76-77). Tiranlık ise benzer şekilde, tek kişinin yönetimi ve despotizm olarak adlandırılmaktadır. Aristokrasi ve oligarşi yönetim sistemlerinde ise ayrıcalıklı bir sınıf veya azınlık bir grup yönetim sürecinde söz sahibi olmaktadir.

Kuvvetler birliğine dayalı hükümet sistemlerinden birisi de meclis hükümet sistemidir. Meclis hükümet sisteminde yasama ve yürütme erkleri yasama organında toplanmakta, yürütme yasama erkine bağlı hareket etmekte, yasama erki hem yasama hem de yürütme görevlerini yerine getirmekle yükümlü tutulmaktadır (Gözler, 2016, s. 78-79).

Kuvvetler ayrılığı ilkesinden bahsetmek için Montesquieu (2017) tarafından kaleme alınan Kanunların Ruhu Üzerine adlı eserine atıf yapmak gerekmektedir. Kuvvetler ayrılığına dayalı hükümet sistemlerinde, sert kuvvetler ayrılı̆̆ı olarak ifade edilen başkanlık sistemine ve yumuşak kuvvetler ayrılığı olarak şekillendirilen parlamenter sisteme atıf yapılmaktadır.

"Yürütme iktidarının, yasama iktidarından kaynaklandığı ve ona karşı sorumlu parlamenter sistemlerde; yasama ve yürütme organlarının birbirleri arasında kesin çizgi olmamakla beraber yumuşak şekilde ayrıldığı görülmektedir. Parlamenter sistemlerde, yürütme organı iki başlıdır ve yürütme yetkisi devlet başkanı (cumhurbaşkanı) ve bakanlar kurulundadır. Parlamenter sistemlerde, Siyasal bakımdan tam sorumsuz bir devlet başkanlığı (cumhurbaşkanı) vardır. Hükümet ve kabine yasama organına karşı sorumludur. Yasama ve yürütme birbirinden bağımsız olmakla beraber aralarında işbirliği ve etkileşim vardır. Parlamenter sistemlerde yasama organının güvensizlik oyu vererek hükümeti düşürebilme yetkisine karşlık, yürütme organı da yasama organını feshedebilme yetkisine sahiptir. Parlamenter sistemde aynı kişi hem yasama da hem yürütme de görev alabilmektedir (Gözler, 2015, s. 246-247).

Sert kuvvetler ayrılığının yansıması olan başkanlık sisteminde ise; yasama ve yürütme arasında sert kuvvetler ayrılığı bulunmaktadır. Yürütme organı tek kişiden müteşekkildir ve devlet başkanı eliyle yürütülmektedir. Devlet başkanı doğrudan halk tarafından seçilmektedir. Yürütme organında yer alan bakanlar/kabine üyeleri başkan tarafından görevlendirilmektedir. Başkan yasama organının çalışmasına katılamamaktadır. Yürütme yasamanın güvenine dayanmamaktadır. Bu bağlamda, yasama organı güvensizlik oyu verip başkanı düşürememekte, başkan da, "yasama organı" olan kongreyi feshedememektedir. Başkanlık sisteminin temel ilkesi olan yasama ve yürütme organlarının ayrı olması hususundan dolayı, bir kişi hem yasama da hem yürütme de görev alamamaktadır (Gözler, 2015, s. 246). Son olarak, check-balance (denge-fren) sistemine istinaden kuvvetlere birbirini kontrol etme imkanı sağlanmaktadır.

Hükümet sistemleri hakkında bilgi verildikten sonra, Türkiye'de yaşanan hükümet sistemleri ve özellikle Cumhurbaşkanlığı Hükümet sistemine zemin hazırlayan süreç hakkında kısaca bilgi verilmesi çalışmanın bütünlüğü açısından önem arz etmektedir. Osmanlı'da klasik dönemde hüküm süren Mutlak Monarşi anlayışı, 1876 yılında kabul edilen Kanun-i Esasi ile birlikte Meşruti Monarşi düşüncesine doğru evrilmeye başlanmış, 1908 yılında kabul edilen II. 
Meşrutiyet ile birlikte 1876 Anayasa'sı revize edilerek padişahın yetkileri net olarak sınırlandırılmış ve Anayasal/Parlamenter Monarşi anlayışı hüküm sürmeye başlamıştır.

Türkiye Cumhuriyeti kuruluş aşaması sürecinde 1921 Anayasası ile birlikte savaş koşulları da dikkate alınarak, hızlı karar verebilmek adına yasama ve yürütme yetkileri mecliste toplanmış ve bu süreçte Meclis Hükümeti sistemi uygulanmıştır. 1924 yılında kabul edilen Teşkilat-1 Esasiye Kanunu ile Anayasası ile birlikte Parlamenter Sisteme geçiş için önemli adımlar atılmış fakat Meclis Hükümet Sisteminin yansımaları bazı düzenlemelere yer verilmiştir. Kuvvetler birliği ve görevler ayrılığının benimsenmeye çalışıldığı dikkati çekmektedir (Gözler, 2015 s. 39). 1961 Anayasası ile parlamenter hükümet sistemi daha açık bir şekilde uygulanmaya başlanmış ve 1982 Anayasası ile Cumhurbaşkanının yetkilerinin güçlendirildiği saf bir parlamenter sistem hayata geçirilmiştir.

Türkiye'de 2007 yılında gerçekleştirilen referandumla anayasa değişikliğine gidilmiş, 5678 sayılı Kanunla 1982 Anayasa'sının 101 ve 102. maddelerinde yapılan değişikliklerle Cumhurbaşkanının halk tarafından seçilmesine imkân sağlanmıştır. 10 Ağustos 2014 tarihinde gerçekleştirilen Cumhurbaşkanlığ 1 Seçimi ile ilk defa cumhurbaşkanı halk tarafından seçilmiş ve parlamenter sistemden fiili olarak uzaklaşılmıştır (Gözler, 2015, s. 247-248).

16 Nisan 2017 yılında yapılan referandumla, anayasa değişikliği Cumhurbaşkanlığı Hükümet Sistemine geçilmiş; milletvekili sayısı 550'den 600'e çıarılmış, seçilme yaşı 18'e indirilmiş, daha önce 4 yılda bir yapılan milletvekili genel seçimlerinin 5 yılda bir yapılmasına yönelik değişikliğe gidilmiştir. Bununla birlikte, Türkiye Büyük Millet Meclisi ve Cumhurbaşkanlığ1 seçimleri beş yılda bir aynı günde yapılacağına dair anayasal hüküm ortaya konulmuştur. 6771 sayılı kanunla 1982 Anayasası'nın 102. Maddesi mülga edilmiş ve anayasanın 101. Maddesinde Cumhurbaşkanın adaylık ve seçimi ile ilgili değişikliklere gidilmiştir:

Cumhurbaşkanı, kırk yaşını doldurmuş, yükseköğrenim yapmış, milletvekili seçilme yeterliliğine sahip Türk vatandaşları arasından, doğrudan halk tarafından seçilir. Cumhurbaşkanının görev süresi beş yıldır. Bir kimse en fazla iki defa Cumhurbaşkanı seçilebilir. Cumhurbaşkanı seçilen milletvekilinin TBMM üyeliği sona erer.

Genel oyla yapılacak seçimde, geçerli oyların salt çoğunluğunu alan aday Cumhurbaşkanı seçilir. İlk oylamada bu çoğunluk sağlanamazsa, bu oylamayı izleyen ikinci pazar günü ikinci oylama yapılır. Bu oylamaya, ilk oylamada en çok oy almış iki aday katılır ve geçerli oyların çoğunluğunu alan aday Cumhurbaşkanı seçilir. İkinci oylamaya katılmaya hak kazanan adaylardan birinin herhangi bir nedenle seçime katılmaması halinde; ikinci oylama, boşalan adaylığın birinci oylamadaki sıraya göre ikame edilmesi suretiyle yapılır. İkinci oylamaya tek adayın kalması halinde, bu oylama referandum şeklinde yapılır. Aday, geçerli oyların salt çoğunluğunu aldığı takdirde Cumhurbaşkanı seçilir. Oylamada, adayın geçerli oyların çoğunluğunu alamaması halinde, sadece Cumhurbaşkanı seçimi yenilenir. Seçimlerin tamamlanamaması halinde, yenisi göreve başlayıncaya kadar mevcut Cumhurbaşkanının görevi devam eder. 
Cumhurbaşkanlığı Hükümet Sistemi ile getirilen değişikliklerden bazıları şu şekilde siralanabilir (Akman, 2019, s. 40-41):

- Başbakanlık ve bakanlar kurulu kaldırılarak çift başlılığa son verilmiştir.

- Yürütme erki tek başlı hale getirilmiş ve yürütme yetkisi Cumhurbaşkanına verilmiştir. Cumhurbaşkanı, Cumhurbaşkanı yardımcılarını ve bakanları atayacaktır.

- Cumhurbaşkanına yürütme yetkisi dahilinde kararname çıkarma yetkisi verilmiştir.

- Cumhurbaşkanı, üst düzey kamu görevlilerini, Cumhurbaşkanlığı kararnameleri ile atayacaktır.

- Cumhurbaşkanı seçilen kişinin, varsa partisi ile ilişiği kesilir hükmü anayasadan kaldırılmıştır.

- Cumhurbaşkanına cezai sorumluluk getirilmiştir. Parlamenter sistemde yer alan, Cumhurbaşkanının siyasi sorumsuzluk ilkesi kaldırılarak, yeni sistemle birlikte halk tarafından seçilen Cumhurbaşkanının siyasi ve diğer konularda sorumlu olması hükme bağlanmıştır.

- Parlamenter sistemde yer alan, parlamentonun denetim yollarından birisi olan gensoru mekanizması kaldırılmış, Cumhurbaşkanı halk tarafından doğrudan seçildiği için, Cumhurbaşkanı ve kabinesi için güven oylamasına ihtiyaç kalmamıştır.

- Cumhurbaşkanına bütçe yasa teklifinde bulunma yetkisi verilmiş, diğer yasa tekliflerinin milletvekilleri aracılığıyla gerçekleştirileceği yönünde anayasal düzenleme getirilmiştir.

- Cumhurbaşkanına meclisi feshetme yetkisi verilmiş, meclise de Cumhurbaşkanını yargılayabilme yetkisi tanınmıştır. Cumhurbaşkanın meclisi feshetmesi veya Cumhurbaşkanın yargılanıp azlledildiği durumlarda birlikte seçilme kuralı gereğince, hem Cumhurbaşkanlığı hem de Cumhurbaşkanlığı seçimlerinin birlikte yapılacağ hükme bağlanmıştır.

Cumhurbaşkanlığı Hükümet sistemi ile birlikte, seçimlere yönelik olarak siyasi partiler arası seçim ittifaklarına imkan sağlayan yasal düzenleme hayata geçirilmiştir. 13 Mart 2018 tarihinde kabul edilen 7102 sayılı "Seçimlerin Temel Hükümleri ve Seçmen Kütükleri Hakkında Kanun ile Bazı Kanunlarda Değişiklik Yapılmasına Dair Kanun” 30362 numarası ile Resmi Gazete 'de yayınlanarak yürürlüğe girmiştir. Milletvekili ve Cumhurbaşkanlığı seçimlerinde ve Mahalli İdareler Seçimlerinde siyasi partilerin ortak aday çıkarabilecekleri ve ittifak ortak adayına yönelik bilgilerin seçim pusulalarına dahil edileceği belirtilmiştir.

"Seçim İttifakı

MADDE 12/A- Seçimlere katılma yeterliliği taşıyan siyasi partiler, ittifak yaparak seçime katılabilir. İttifak yapan siyasi partiler, kendi aday listelerini verir.

İttifak yaparak seçime katılma kararı alan siyasi partiler, seçimin başlangıç tarihinden itibaren en geç yedi gün içinde, genel başkanların imzalarını ihtiva eden ittifak protokolünü Yüksek Seçim Kuruluna teslim eder. Aday listelerinin teslim edilmesi için belirlenen tarihten iki gün öncesine kadar, aynı usulle ittifak protokolünde değiş̧iklik yapılabilir.

İttifak protokolünde; siyasi partilerce belirlenmesi halinde, ittifak unvanı ve kanunlara aykırı olmayan diğer hususlar yer alır. 
Siyasi partiler, aday listelerinin teslim edilmesi için belirlenen tarihten üç gün öncesine kadar, Yüksek Seçim Kuruluna bildirimde bulunmak suretiyle ittifaktan vazgeçebilir. Bu durum, Yüksek Seçim Kurulunca aynı ittifak içerisindeki diğer siyasi partilere derhal bildirilir. Vazgeçme halinde, ittifak diğer partiler arasında devam eder. İttifaktan vazgeçmenin bildirilmesini takip eden gün saat 17.00 'ye kadar, ittifak içerisindeki diğer siyasi partiler ittifak protokolünü değiştirebilir veya ittifaktan vazgeçebilir.

Bu maddenin uygulanmasına ilişkin usul ve esaslar ile seçim ittifakına ilişkin diğer hususlar Yüksek Seçim Kurulunca belirlenir.”

2839 sayılı Kanunun $26 \mathrm{ncı}$ maddesinin birinci fikrasının (b) bendine aşağıdaki paragraf eklenmiştir.

"İttifak yapan siyasi partiler, kuraya ittifak olarak dâhil edilir ve oy pusulasında yan yana yer alır. Bu partilerin ittifak içerisindeki sıraları da kurayla belirlenir. İttifak yapan siyasi partilerin sütunlarının üzerinde; kısa kenarı iki santimetre, uzun kenarı bu partilerin sütunlarının genişliği ile sütunlarının aralığı toplamı kadar olan, dikdörtgen şeklinde ittifak unvanının yer alacağı ortak bir bölüm bulunur. İttifakın unvanı yoksa, ittifak unvanı bölümüne yalnız “İTTİFAK” ibaresi yazılır. Unvanı olmayan ittifakın birden fazla olması halinde, bunlar başvuru sırasına göre numaralandırılır. İttifak unvanı bölümü ile aralarındaki boşluk dâhil ittifak yapan siyasi partilerin sütunlarının tamamı ittifak alanıdır."

2839 sayılı Kanunun 29 uncu maddesinin birinci fikrasına aşağıdaki cümleler eklenmiştir. "Ancak aynı ittifak içerisindeki siyasi partilerin her birinin geçerli oyu; ittifakı oluşturan siyasi partilerin o seçim çevresinde tek başına aldıkları oy sayısına, ittifakın ortak oylarından gelen payın ilave edilmesiyle elde edilir. İttifak yapan her bir partiye ortak oylardan gelen pay; ittifak yapan siyasi partilerin tek başına aldıkları oyun bu partilerin toplam oyuna bölünmesi ile elde edilen katsayının ittifakın ortak oyu ile çarpımı sonucu elde edilir."

2839 sayılı Kanunun 16 ncı maddesine ikinci fikradan sonra gelmek üzere aşağıldaki fikra eklenmiştir. "Seçimlere katılma yeterliliği taşıyan siyasi partinin seçime katılmaması halinde, bu partinin üyesi, kendisinin ve üyesi olduğu siyasi partinin yazılı muvafakati alınarak, başka bir siyasi parti tarafından aday gösterilebilir." Yukarıda ifade edilen hususlar dikkate alındığında, siyasi partiler arası ittifaka dâhil olmayan ve seçime katılmayan siyasi parti adaylarının başka bir siyasi parti listesinden seçime girmesine imkan sağlanmıştır. Bu şekilde doğrudan ittifakın yanında, örtülü bir ittifaka zemin hazırlanmıştır. 


\section{Araştırmanın Yöntemi}

Çalışmanın bu kısmında, seçmenlerin siyasi partiler arası ittifaka yönelik algılarını belirlemeye yönelik Karaman il merkezinde gerçekleştirilen alan araştırmasının yöntemi ele alınmaktadır. Bu kapsamda, araştırmanın amacı ve soruları, araştırmanın evren ve örneklemi, araştırmanın sınırlılıkları, veri toplama araçları, verilerin toplanması ve verilerin analizi konularına değinilmektedir.

\section{Araştırmanın Amacı ve Soruları}

Türkiye'de 2018 yılında hükümet sistemi değişikliğine gidilerek, parlamenter hükümet sisteminden, Cumhurbaşkanlığı hükümet sistemine geçilmiştir. Sistem değişikliği ile birlikte gerçekleştirilen, Cumhurbaşkanlığı seçimleri ve Yerel seçimlerle birlikte siyasi partiler arası ittifak uygulamasına gidilmiştir. Siyasi partiler arasında uygulanan seçim ittifaklarına yönelik vatandaşların algısının, Karaman il merkezinde gerçekleştirilen alan araştırılması ile ölçülmesi araştırmanın temel amacını oluşturmaktadır. $\mathrm{Bu}$ amaç doğrultusunda uygulamaya konulan araştırma kapsamında belirlenen ve cevabı aranan sorular şu şekilde sıralanabilir:

- Siyasi partiler arası seçim ittifaklarının yapılması seçmenlerin oy verme davranışlarında değişikliğe yol açtı mı?

- Siyasi partiler arası seçim ittifaklarının yapılması seçmenlerin oy verdiği parti için faydalı oldu mu?

- Seçmenler siyasi partiler arası yapılan seçim ittifakı uygulamasının içeriği hakkında bilgi sahibi midir?

- Siyasi partilerin ittifak hakkında siyasal bilgilenmede kitle iletişim araçları etkili oldu mu?

- Siyasi partilerin ittifakı hakkında siyasal bilgilenme seçmenlerin oy vermelerinde etkili oldu mu?

- Siyasi partiler arası ittifak yapılması parti bağlılığına değişiklik yaratmış mıdır?

\section{Araştırmanın Evren ve Örneklemi}

Araştırmanın evrenini; Karaman ili merkezi içerisinde yaşayan ve Karaman il merkezi nüfusuna kayıtlı olan seçmenler oluşturmaktadır. Karaman Valiliğinden alınan bilgilere göre 2018 yılı nüfus sayımı sonuçlarına göre, Karaman il genelinde toplam 251.913 kişi yaşamaktadır. Karaman il merkezinin beldeler ve köyler dahil toplam nüfusu 194.018 olup, sadece il merkezinde yaşayan kişilerin sayısı 161.946'dır (www. karaman.gov.tr, 2019). 31 Mart 2019 mahalli idareler seçimlerinde Karaman il merkezinde oy kullanması gereken toplam seçmen sayısı 108.660'dır (secim.haberler.com, 2019). Buradan hareketle araştırmanın evrenini il merkezinde oy kullanması gereken seçmenler oluşturmaktadır.

Örneklem büyüklügü ise \%95 Güven Düzeyi ve \%5 Hata Payı oranları dikkate alındığında, evren içerisinde evren içinde örneklem en az 383 kişi olarak öngörülmüştür. Araştırma içerisinde gerçekleşebilecek olası sorunlar da göz önünde bulundurularak 400 kişi esas örneklem olarak seçilmiştir. Araştırma kapalı uçlu sorulardan oluşmuş anket formlarıyla, 400 
kişiden oluşan basit tesadüfi örneklem kitlesi üzerinde seçmen niteliğine sahip on sekiz ve üzeri yaştaki kişilerden seçilmiştir.

Basit tesadüfî örnekleme (simple random sampling). Her bir örnekleme birimine eşit seçilme ihtimalinin verilmesiyle (seçilen birimin yerine konulmasıyla) seçilen birimlerin örnekleme alındığ 1 türe basit tesadüfî örnekleme adı verilmektedir. Bu örnekleme türünde evrendeki tüm birimlerin örnekleme seçilme olasılığı aynıdır. Dolayısıyla da örnekleme seçilen bir birimin seçimi diğer birimlerin seçimini etkilememektedir (Büyüköztürk vd., 2012; Altunışık vd., 2005).

\section{Araştırmanın Kısıtıııkları}

Araştırma Karaman il merkezinde yaşayan seçmenlere yönelik olarak gerçekleştirilmiştir. Karaman il merkezinde yapılması sebebiyle, araştırma anketin yapıldı̆̆ sınırlıdır ve elde edilen bulgu ve sonuçların ülke bütününe genellenmesi amaçlanmamaktadır. Araştırma, Eylül-Kasım 2019 tarihleri arasında gerçekleştirilmiştir ve katılımcıların zamanla algıların değişebileceği düşünüldügünden, araştırma yapıldığı zamanla sınırlıdır.

\section{Veri Toplama Araçları, Verilerin Toplanması ve Analizi}

Araştırmada veri toplama aracı olarak konu ile ilgili literatür taranarak oluşturulan "Siyasi Partiler Arası Seçim İttifaklarına Yönelik Vatandaş Algısı” başlıklı anket formu” kullanılmıştır. Formun hazırlanması noktasında konu ile ilgili literatür taranmış görüşme soruları bu çalışmanın yazarları tarafından hazırlanmıştır.

Araştırma verilerinin toplanmasında 31 soru oluşturulmuştur. Anket üç bölümden oluşmaktadır. Birinci bölümde demografik sorular ve seçmenlerin milletvekili, yerel seçimlerde cumhurbaşkanlığı seçimi ve referandumda oy kullanıp kullanmadığı dair bilgilerden oluşmaktadır. İkinci bölümde seçmenlerin oy verme davranışları ve oy kullanmalarını etkileyen faktörlerin neler olduğu, Türkiye'de uygulanan siyasi partiler arası ittifak uygulamasının içeriği hakkında bilgi sahibi olup olmadığı, siyasi partilerin ittifak yapılmasının oy verdiği partiye olan bağlılığını nasıl etkilediği, siyasi partilerin ittifak yapması partiler açısından nasıl değerlendirildiği, siyasi partilerin ittifak yapmalarının nedenlerini ortaya koymayı amaçlayan sorulardan oluşmaktadır. Üçüncü bölüm siyasi partilerin ittifak yapmalarının seçmenlerin görüşlerini ortaya koyan 5'li Likert ölçeği ile ölçen 15 ifade oluşturulmuştur. 5’li likert ölçeğinde, Kesinlikle Katılmıyorum(1), Katılmıorum(2), Kararsızım(3), Katliyorum(4), Kesinlikle katılıyorum(5) Aralıklarında cevaplar alınmıştır

Araştırmada, nicel veri toplama analiz yöntemlerinden birisi olan anket tekniğinden yararlanılmıştır. Alan araştırması katılımcılarla yüz yüze anket uygulamasıyla gerçekleştirilmiştir. Elde edilen veriler SPSS istatistik program kullanılarak elektronik ortamda işlenmiştir. $\mathrm{Bu}$ veriler ışı̆̆ında Karaman İli merkez seçmeni ile gerçekleştirilen anket uygulaması sonucunda veriler elde edilmiştir. İl merkezinde yaşayan 400 seçmene ulaşılarak, anket tekniği kullanılmıştır

Araştırmaya katılan vatandaşlara yönelik gerçekleştirilen anket çalışması sonucunda elde edilen verilerin analizinde sırasıyla; katılımcıların demografik özelliklerini belirlemek amacıyla 
frekans analizi, faktör analizi, Ki-kare testi, cinsiyete göre Bağımsız Örneklem T-Testi; yaş, eğitim ve gelir düzeyindeki farklılaşmayı ortaya koymak için de Tek Yönlü Varyans Analizi (ANOVA) kullanılmıştır. Gerçekleştirilen analiz sonucunda elde edilen veriler tablolara ve yazıya aktarılmıştır.

\section{Araştırmanın Bulguları}

Çalışmanın bu kısmında araştırma sonucunda elde edilen bulgulara ve bulguların analizine yer verilmektedir. Bu kapsamda sırasıyla, araştırmanın geçerlilik ve güvenilirlik testleri, faktör analizi sonuçlar, demografik sonuçlar ve siyasi partiler arası seçim ittifakına yönelik vatandaş algılarını içeren bulgular üzerinden değerlendirmeler yapılmaktadır.

\section{Araştırmanın Geçerlilik ve Güvenilirliği ve Faktör Analizi}

$\mathrm{Bu}$ çalışmada yapılan geçerlik ve güvenilirlik analizi sonucunda elde edilen Cronbach's Alpha değeri 0,763dur ${ }^{3}$. Alan araştırması kapsamında oluşturulan ölçek dört faktörden oluşmaktadır. Bu faktörler (siyasi parti bağlılığı, siyasal bilgilendirme, yeni bir siyasi model, siyasi parti ittifakının nedenleri)oluşmaktadır ve faktörler toplam varyansın \%62,809'nu açıklamaktadır. Örneklem yeterliliğini ölçmek amaciyla uygulanan KMO testi sonucu 0,795 olarak hesaplanmıştır. Ölçekte belirlenen 5 faktöre ait özdeğerler ve bunların varyans açıklama oranları Tablo 1'de verilmiştir. Ayrıca, araştırma kapsamında belirlenen faktöre ait madde yükleri Tablo 2'de verilmiştir.

\section{Tablo 1. Ölçek Faktörlerinin Varyans Açıklama Oranları}

\begin{tabular}{|l|r|r|r|}
\hline Faktörler & Özdeğer \% & Varyans Açıklama & Kümülatif \% \\
\hline 1 & 4,229 & 28,195 & 28,195 \\
\hline 2 & 2,644 & 17,625 & 45,820 \\
\hline 3 & 1,333 & 8,886 & 54,706 \\
\hline 4 & 1,215 & 8,103 & 62,809 \\
\hline
\end{tabular}

\footnotetext{
${ }^{3}$ Chronbach Alpha testine göre, güvenilirlik katsayısı 0,60-0,80 değerleri arasında ise ölçeğin oldukça güvenilir olduğu sonucu ortaya
} konulmaktadır (Özdamar, 1999: 520-522) 


\section{Tablo 2. Ölçek Maddelerinin Faktör Yükleri}

\begin{tabular}{|c|c|c|c|c|}
\hline Madde İçeriği & 1 & 2 & 3 & 4 \\
\hline $\begin{array}{l}\text { Siyasi partiler arası ittifak yapılması oy verme davranışımda } \\
\text { değişiklik yaratmıştır }\end{array}$ & & ,497 & & \\
\hline $\begin{array}{l}\text { Cumhurbaşkanlığı Hükümet Sistemi partileri ittifak kurmaya } \\
\text { yöneltmiştir }\end{array}$ & & & ,601 & \\
\hline $\begin{array}{l}\text { Dış politikadan kaynaklı sorunları çözmek için ittifak } \\
\text { kurulmuştur }\end{array}$ & & ,839 & & \\
\hline Terör sorununu çözmek için ittifak kurulmuștur & & ,808 & & \\
\hline Partilerin ittifak yapmas1 yeni bir siyaset modelidir & & & .764 & \\
\hline $\begin{array}{l}\text { Siyasi partiler arası ittifak yapılması, ittifakı oluşturan siyasi } \\
\text { partilerin çıkarları için kurulmuștur }\end{array}$ & & &, 832 & \\
\hline $\begin{array}{l}\text { Sosyal medya, ittifak içinde olan partilerin söylem, aday ve } \\
\text { projelerini tanımamıza etkili olmuştur }\end{array}$ & ,690 & & & \\
\hline İttifaklar siyasi partilerin baraj kaygılarından doğmuştur &, 716 & & & \\
\hline $\begin{array}{l}\text { Önümüzdeki siyasi süreçte hiçbir partinin tek başına iktidar olma } \\
\text { şansı yoktur }\end{array}$ & ,781 & & & \\
\hline $\begin{array}{l}\text { Seçim döneminde ittifaklar yazılı ve görsel medya açısından } \\
\text { önemli gündem olmuştur }\end{array}$ & ,766 & & & \\
\hline $\begin{array}{l}\text { Seçim süreci içerisinde siyasi partilerin ittifak haberleri çeşitli } \\
\text { kitle iletişim araçlarında yapılan siyasi kampanyalar siyasal } \\
\text { tercihimde etkili olmuştu }\end{array}$ & 677 & & & \\
\hline $\begin{array}{l}\text { Siyasi partiler arası ittifakların devam etmesi gerektiğini } \\
\text { düsünüyorum }\end{array}$ & & & & ,709 \\
\hline $\begin{array}{l}\text { Yazılı ve görsel medya ittifak içinde olan partilerin söylem, aday } \\
\text { ve projelerini tanımamızda etkili olmuștur }\end{array}$ & ,699 & & & \\
\hline
\end{tabular}

\section{Sosyo-Demografik Bulgular}

Bu kısımda, araştırmaya dâhil olan seçmenlerin, sosyo-demografik özelliklerini (yaş, cinsiyet, eğitim durumu, gelir durumu, şehirdeki ikamet süresi, STK ve/veya sendikaya üyelik gibi) içeren bilgi ve bulgulara aşağıdaki tablolarda yer verilmektedir. 
Tablo 3. Katılımcıların Sosyo-Demografik Özelliklerine Göre Dağılımları

\begin{tabular}{|c|c|c|}
\hline Cinsiyet & $\mathbf{N}$ & $\%$ \\
\hline Erkek & 243 & 60,8 \\
\hline Kadın & 157 & 39,2 \\
\hline Toplam & 400 & 100,0 \\
\hline Yaș & $\mathbf{N}$ & $\%$ \\
\hline $18-28$ & 108 & 27,0 \\
\hline $29-39$ & 140 & 35,0 \\
\hline $40-50$ & 104 & 26,0 \\
\hline $51-61$ & 29 & 7,2 \\
\hline 62 ve üstü & 19 & 4,8 \\
\hline Toplam & 400 & 100,0 \\
\hline Ĕgitim & $\mathbf{N}$ & $\%$ \\
\hline İlkokul & 65 & 16,2 \\
\hline Ortaokul & 49 & 12,2 \\
\hline Lise & 106 & 26,5 \\
\hline Önlisans & 100 & 25,0 \\
\hline Lisans & 74 & 18,5 \\
\hline Yüksek Lisans & 6 & 1,5 \\
\hline Toplam & 400 & 100,0 \\
\hline Gelir & $\mathbf{N}$ & $\%$ \\
\hline $1000 \mathrm{TL}$ alt1 & 88 & 22,0 \\
\hline $1001-2000 \mathrm{TL}$ & 59 & 14,8 \\
\hline $2001-4000 \mathrm{TL}$ & 155 & 38,8 \\
\hline 4001-6000 TL & 68 & 17,0 \\
\hline $6001-8000 \mathrm{TL}$ & 25 & 6,2 \\
\hline $8001-10000 \mathrm{TL}$ & 5 & 1,2 \\
\hline Toplam & 400 & 100,0 \\
\hline Karamanda İkamet Süresi & $\mathbf{N}$ & $\%$ \\
\hline $0-5$ y1l & 71 & 17,8 \\
\hline $6-10$ y1l & 70 & 17,5 \\
\hline $11-15 \mathrm{y} 1 \mathrm{l}$ & 66 & 16,5 \\
\hline 16 yil ve üstü & 193 & 48,2 \\
\hline Toplam & 400 & 100,0 \\
\hline Sivil toplum kuruluşuna ve/veya sendikaya üye olma & $\mathbf{N}$ & $\%$ \\
\hline Evet & 85 & 21,2 \\
\hline Hayır & 315 & 78,8 \\
\hline Toplam & 400 & 100,0 \\
\hline Genel seçimlerde (milletvekili seçimlerinde) oy kullanma & $\mathbf{N}$ & $\%$ \\
\hline Evet & 372 & 93,0 \\
\hline Hayır & 28 & 7,0 \\
\hline Toplam & 400 & 100,0 \\
\hline Yerel seçimlerde oy kullanma & $\mathbf{N}$ & $\%$ \\
\hline Evet & 386 & 96,5 \\
\hline Hayır & 14 & 3,5 \\
\hline Toplam & 400 & 100,0 \\
\hline Cumhurbaşkanlığı seçimlerinde oy kullanma & $\mathbf{N}$ & $\%$ \\
\hline Evet & 363 & 90,8 \\
\hline Hayır & 37 & 9,2 \\
\hline Toplam & 400 & 100,0 \\
\hline
\end{tabular}


- Tablo 3 incelendiğinde katılımcıların cinsiyet dağılımına baktığımızda \%60,8’ni erkek seçmenler ve \%39,2'i kadın seçmenlerden oluşmaktadır.

- Araştırmaya katılan seçmenlerin yaş dağılımı \%27,0'i 18- 28 yaş aralığında, \%35,0'i 2939 yaş aralığında, \%26,0'sı40-50 yaş aralığında, \%7,2'si 51-61 yaş aralığın ve \%4,8'i 62 ve üstü yaş aralığındadır.

- Araştırmaya katılan seçmenlerin eğitim durumları \%16,2'si İlkokul, \%12,2'si ortaokul, \%26,5'sı, lise \%25,0'si ön lisans, \%18,5 lisans, \%2,8'i yüksek lisans eğitime sahiptir.

- Araştırmaya katılan seçmenlerin gelir düzeylerinin dağılımı \%22,0'i 1000 TL alt1, \%14,8'i 1001-2000 TL arası, \%38,8'i 2001-4000 TL arası, \%17,0'i 4001-6000 TL arası, \%6,2'si 6001-8000 TL arası, \%1,2'i 8001-10000 TL arası gelir düzeyinde olduğu görülmektedir

- Araştırmaya katılan seçmenlerin Karaman ilinde ikamet sürelerine bakıldığında \%17,8'i 0-5 yıl arası, \%17,5'i 6-10 yıl arası, \%16,5'i 11-15 yıl ve \%48,2'si ise 16 yıl ve üstü yıl aralığında ikamet ettikleri söylenilebilir.

- Araştırmaya katılan seçmenlerin, sivil toplum kuruluşuna ve/veya sendikaya üye olma durumuna bakıldığında \%21,2'nin üye olduğu, \%78,8'nin ise sivil toplum kuruluşuna veya sendikaya üye yönünde görüş beyan ettikleri dikkati çekmektedir.

- Araştırmaya katılan seçmenlerin genel seçimlerde (milletvekili seçimlerinde) oy kullanma durumuna bakıldığında \%93,0’ü milletvekili seçiminde oy kullandığını, \%7,0'si oy kullanmadığını belirtmiştir.

- Araştırmaya katılan seçmenlerin yerel seçimlerde oy kullanma durumuna bakıldığında, \%96,5’i yerel seçimlerde oy kullandığı, \%3,5’i oy kullanmadıklarını görülmektedir.

- Araştırmaya katılan seçmenlerin Cumhurbaşkanlığı seçimlerinde oy kullanma durumuna bakıldığında, \%90,8’i Cumhurbaşkanlığı seçimlerinde oy kullandığı, \%9,2’i oy kullanmadıkları yönünde sonuç elde edilmiştir.

- Araştırmaya katılan seçmenlerin Referandumda oy kullanma durumuna baktığımızda \%84,8’i Referandumda oy kullandığı, \%15,2’i oy kullanmadıkları görülmektedir.

\section{Siyasi Partiler Arası İttifak Uygulamalarına İlişkin Seçmen Algısına Yönelik Bulgular}

Araştırmanın bu kısmında, katılımcıların partiler arası ittifak uygulamalarına ilişkin algılarını ölçmek amacıyla sorulan sorulardan elde edilen bulgulara yer verilmiştir.

Tablo 4. Bir Siyasi Partiye Oy Verirken Seçmenler İçin Önemli Unsurların Dağılımı

\begin{tabular}{|l|c|c|}
\hline $\begin{array}{l}\text { Bir siyasi partiye oy verirken sizin için en önemli } \\
\text { unsur }\end{array}$ & $\mathbf{N}$ & $\mathbf{\%}$ \\
\hline Parti liderinin imaj1 & 40 & 10,0 \\
\hline Partinin adayları & 91 & 22,8 \\
\hline Partinin ideolojisi & 60 & 15,0 \\
\hline Parti tüzüğü ve parti programı & 32 & 8,0 \\
\hline Partinin projeleri & 177 & 44,2 \\
\hline Toplam & 400 & 100,0 \\
\hline
\end{tabular}


Tablo 4 incelendiğinde katılımcıların bir siyasi partiye oy verirken önemli gördükleri unsurlara bakıldığında seçmenlerin \%44,2'lik oranla partinin projelerinin en önemli unsur olarak görmektedir. Seçmenler için ikinci en önemli unsur \%22,8 oranla parti adaylarıdır. \% 15,0 oranla parti ideolojisi, \%10,0 oranla parti liderinin imajının önemli olduğu ve $\% 8,0$ oranla parti tüzüğü ve parti programını seçmenlerin siyasi partiye oy verirken önemli gördüklerini söylenilmesi mümkündür. Bu bağlamda seçmenler tarafından bir siyasi partiye oy verirken önem verdiği unsur olarak parti projelerini öncelikli olarak değerlendirdiği söylenilebilir.

Tablo 5. Seçmenlerin Seçimlerde Oy Verme Davranışın Etkileyen Faktörler

\begin{tabular}{|l|c|c|}
\hline $\begin{array}{l}\text { Seçimlerde oy verme davranışınızı/oy kullanmanızı etkileyen } \\
\text { faktör/faktörler }\end{array}$ & N & \% \\
\hline Ülkenin geleceğinde etkili olacağım için oy kullanırım & 271 & 67,6 \\
\hline Yasal zorunluluk olduğu için oy kullanırım & 119 & 29,7 \\
\hline Adayları tanıdığım için oy kullanırım & 38 & 15,0 \\
\hline Kişisel çıkarım için oy kullanırım & 16 & 8,0 \\
\hline Adayın mensubu olduğu parti & 64 & 44,2 \\
\hline Bir șeylerin değișebileceğine inandığım için oy kullanırım & 204 & 50,9 \\
\hline Vatandaş̧ık görevi olduğu için oy kullanırım & 232 & 57,9 \\
\hline Mensubu olduğum partiyi desteklemek için oy kullanırım & 114 & 28,4 \\
\hline Adayların temsil yeteneğinin olması & 90 & 22,4 \\
\hline Adayın halktan biri olması & 131 & 32,7 \\
\hline
\end{tabular}

Tablo 5 incelendiğinde katılımcı seçmenlerin seçimlerde oy kullanmaya yönelten faktör ya da faktörlerin etkisinin sonuçları ele alınmıştır. Burada dikkat edilmesi gereken husus, bu soruya bir kişinin birden fazla cevap verebilme hakkının olmasıdır. Seçmenlerin yarısından fazlasının vatandaşlık görevi olduğu için oy kullandığı, seçmenlerin yarısının ise mevcut durum üstünden bir şeylerin değiştirebilmek amacıyla oy kullandığı görülmektedir. Seçmenlerin büyük bir kısmının da adayların mensup olduğu parti sebebiyle oy kullandığı söylenilebilir. Seçimlerde oy verme davranışı etkileyen faktörler incelendiğinde seçmenleri en çok etkileyen faktörün \% 67,6 oranla ülke geleceğinde etkili olabileceği için oy kullandığı düşüncesidir.

Tablo 6. Türkiye'de Siyasi Partiler Arası Yapılan Seçim İttifakı Uygulamasının Konusunda Katılımcıların Haberdarlık Durumu

\begin{tabular}{|l|c|c|}
\hline $\begin{array}{l}\text { Türkiye genelinde siyasi partiler arası yapılan seçim ittifakı } \\
\text { uygulamasının içeriği hakkında bilgi sahibi misiniz? }\end{array}$ & $\mathbf{N}$ & $\mathbf{\%}$ \\
\hline Hayır, hiçbir bilgim yok. & 123 & 30,8 \\
\hline Siyasi partilerin seçim ittifakının sadece varlığından haberdarım & 77 & 19,2 \\
\hline $\begin{array}{l}\text { Siyasi partilerin seçim ittifakından haberdarım ve ittifakların hangi partiler } \\
\text { arasında gerçekleştirildiği hakkında da bilgi sahibiyim. }\end{array}$ & 200 & 50,0 \\
\hline Toplam & 400 & 100,0 \\
\hline
\end{tabular}

Tablo 6 incelendiğinde katılımcıların, siyasi partiler arası yapılan seçim ittifakı uygulamasının içeriği hakkında bilgi sahibi olup olmadığı hususu incelendiğinde; seçmenlerin \%30,8'nin siyasi 
partilerin seçim ittifakından hiç bilgi sahibi olmadığı görülürken; seçmenlerin \%19,2'sinin ise siyasi partilerin seçim ittifakının sadece varlığından haberdar olduğunu içerik hakkında bilgilerinin olmadığ1 yönünde görüş beyan etmişlerdir. Seçmenlerin \%50,0’nin siyasi partilerin seçim ittifakından haberdar olduğunu ve ittifakların hangi partiler arasında gerçekleştirildiği hakkında da bilgi sahibi oldukları görülmektedir. Bu bağlamda seçmenlerin sadece yarısının "hem siyasi partilerin seçim ittifakından haberdar olduğu hem de ittifakların hangi partiler arasında gerçekleştirildiği hakkında bilgi sahibi olduğu" söylenebilir.

\section{Tablo 7. Türkiye’de Siyasi Partiler Arası İttifak Yapılması Seçmenlerin Oy Verdiği Partiye Olan Bağlılı̆̆ını Etkileme Durumu}

\begin{tabular}{|l|c|c|}
\hline $\begin{array}{l}\text { Siyasi partilerin seçim ittifakında bulunmaları oy verdiğiniz partiye olan } \\
\text { bağlılığınızı nasıl etkiledi? }\end{array}$ & $\mathbf{N}$ & $\mathbf{\%}$ \\
\hline $\begin{array}{l}\text { Türkiye genelinde siyasi partiler arası ittifak yapılması sebebiyle, oy } \\
\text { kullanmadım. }\end{array}$ & 41 & 10,2 \\
\hline $\begin{array}{l}\text { Türkiye genelinde siyasi partiler arası ittifak yapılması sebebiyle tepki koyarak } \\
\text { başka partilere/başka adaylara oy verdim }\end{array}$ & 62 & 15,5 \\
\hline $\begin{array}{l}\text { Türkiye genelinde siyasi partiler arası ittifak yapılması sebebiyle sadece kendi } \\
\text { partimin adayını destekledim ve ittifak adayına oy vermedim }\end{array}$ & 59 & 14,8 \\
\hline $\begin{array}{l}\text { Türkiye genelinde siyasi partiler arası ittifak yapılması sebebiyle hem kendi } \\
\text { partimin adayını destekledim ve hem de ittifak adayına oy verdim }\end{array}$ & 76 & 19,0 \\
\hline $\begin{array}{l}\text { Türkiye genelinde siyasi partiler arası ittifak yapılması sebebiyle, ittifak } \\
\text { partilerin hiçbirine oy vermedim }\end{array}$ & 27 & 6,8 \\
\hline $\begin{array}{l}\text { Türkiye genelinde siyasi partiler arası ittifak yapılması, oy verme davranışımı } \\
\text { etkilemedi }\end{array}$ & 135 & 33,8 \\
\hline Toplam & 400 & 100,0 \\
\hline
\end{tabular}

Tablo 7 incelendiğinde katılımcılara, siyasi partilerin seçim ittifakında bulunmaları oy verdiğiniz partiye olan bağlılığı nasıl etkiledi sorusu yöneltilmiştir. Katılımcıların, \%19,0'u siyasi partiler arası ittifak yapılması sebebiyle hem kendi partisinin adayını desteklediğini ve hem de ittifak adayına oy verdiğini belirtmiştir. \%15,5'i siyasi partiler arası ittifak yapılması sebebiyle tepki koyarak başka partilere/başka adaylara oy verdiğini beyan etmiştir. \%14,8'i siyasi partiler arası ittifak yapılması sebebiyle sadece kendi partisini adayını destekleyerek, ittifak adayına oy vermediğini, \%10,2'si ise siyasi partiler arası ittifak yapılması sebebiyle oy kullanmadığı yönünde görüş bildirmiştir. Katılımcıların \%6,8'inin ise siyasi partiler arası ittifak yapılması sebebiyle, ittifak partilerinin hiçbirine oy vermediği görülmektedir. Seçmenlerin \%33,8'nin siyasi partiler arası ittifak yapılmasının, oy verme davranışlarında değişiklik yaratmadığı görüşündedir. 
Tablo 8. Türkiye’de Siyasi Partiler Arası İttifak Yapılmasının Seçmenlerin Oy Verdiği Partiyi Etkileme Durumu

\begin{tabular}{|l|c|c|}
\hline $\begin{array}{l}\text { Türkiye genelinde siyasi partiler arası ittifak yapılması oy verdiğiniz partiyi } \\
\text { nasıl etkiledi? }\end{array}$ & $\mathbf{N}$ & $\mathbf{\%}$ \\
\hline $\begin{array}{l}\text { Türkiye genelinde siyasi partiler arası ittifak yapılmasının, oy verdiğim parti için } \\
\text { faydalı olduğunu düşünüyorum }\end{array}$ & 122 & 30,6 \\
\hline $\begin{array}{l}\text { Türkiye genelinde siyasi partiler arası ittifak yapılmasının, oy verdiğim parti için } \\
\text { faydalı olmadığını düşünüyorum. }\end{array}$ & 113 & 28,3 \\
\hline Kararsızım & 164 & 41,1 \\
\hline Toplam & 400 & 100,0 \\
\hline
\end{tabular}

Tablo 8 incelendiğinde katılımcıların siyasi partiler arası ittifak yapılması oy verdiğiniz partiyi nasıl etkilediğine sorusuna farklı cevaplar vermiştir. Katılımcıların \%41,1'i kararsız olduğunu, \%30,6’sı siyasi partiler arası ittifak yapılmasının, oy verdiği parti için faydalı olduğunu, \%28,3'ünün ise siyasi partiler arası ittifak yapılmasının, oy verdiği parti için faydalı olmadığını belirtmişledir. Bu bağlamda büyük bir çoğunluğu oluşturan seçmenlerin siyasi partiler arası ittifakın fayda noktasında bir kararsızlık içinde olduğu ve siyasi parti ittifakları konusunda ikna olmadıkları yönünde çıkarımda bulunulabilir.

\section{Tablo 9. Katılımcıların Türkiye'de Siyasi Partiler Arası İttifak Yapılmasının Nedenlerine Yönelik Algıları}

\begin{tabular}{|c|c|c|}
\hline $\begin{array}{l}\text { Türkiye genelinde siyasi partiler arası ittifak yapılmasının neden/nedenleri size göre } \\
\text { nelerdir? }\end{array}$ & $\mathbf{N}$ & $\%$ \\
\hline Seçim sistemi sebebiyle, siyasi partilerin tek başına iktidar olamayacağını düşünmeleri & 201 & 50,1 \\
\hline Siyasi partilerin seçmenlerin gözünde farkındalıklarının kalmayıșı & 109 & 27,2 \\
\hline Seçmenlerin hiçbir partiye güven duymaması & 157 & 41,1 \\
\hline Siyasi partilerin stratejik olarak çıkarlarını düșünmeleri & 239 & 59,6 \\
\hline Siyasi partilerin ittifakı birleștirici bütünleștirici görmeleri & 104 & 25,9 \\
\hline $\begin{array}{l}\text { Cumhurbaşkanlığı Hükümet Sistemi sonucunda partilerin ittifak yapmalarının zorunluluk } \\
\text { haline gelmesi }\end{array}$ & 153 & 38,2 \\
\hline
\end{tabular}

Tablo 9 incelendiğinde katılımcı seçmenlerin siyasi partiler arası ittifak yapılmasının neden/nedenlerine yönelik görüşleri doğrultusunda ortaya konulan sonuçlar ele alınmıştır. Burada dikkat edilmesi gereken husus, bu soruya bir kişinin birden fazla cevap verebilme hakkının olmasıdır.

Katılımcıların, \%59,6’sı siyasi partilerin stratejik olarak çıkarlarını düşündüklerini belirtmiştir. Katılımcıların \%50,1'i seçim sistemi sebebiyle, siyasi partilerin tek başına iktidar olamayacağını düşünmelerinden dolayı; \%41,1 seçmenlerin hiçbir partiye güven duymamasından dolayı ittifak yoluna gidildiğini beyan etmiştir. Katılımcıların \%38,2'si ise Cumhurbaşkanlığı Hükümet Sistemi sonucunda partilerin ittifak yapmalarının zorunluluk haline geldiğini beyan etmiştir. \%27,2'sinin ise siyasi partilerin seçmenlerin gözünde farkındalıklarının kalmayışı sebebiyle ve \%25,9'u ise siyasi partilerin ittifakı bütünleștirici görmeleri nedeniyle siyasi partiler arası ittifak yapıldığ 1 yönünde görüş bildirmişlerdir. Bu bağlamda katılımcı seçmenlerin önemli bir kısmı siyasi partilerin ittifak yapmalarının, siyasi partilerin stratejik olarak çıkarlarını düşünmelerinden dolayı doğduğu görüşündedir. 


\section{Tablo 10. Katılımcıların Cinsiyetleri ve Türkiye'de Siyasi Partiler Arası İttifak} Yapılmasının Nedenlerine Yönelik Algılarının Karşılaştırılması

\begin{tabular}{|c|c|c|c|}
\hline \multirow{2}{*}{$\begin{array}{l}\text { Siyasi partilerin seçim ittifakında bulunmaları oy verdiğiniz } \\
\text { partiye olan bağlılığınızı nasıl etkiledi? }\end{array}$} & \multicolumn{3}{|c|}{ Cinsiyet } \\
\hline & Erkek & Kadın & Toplam \\
\hline \multirow{2}{*}{$\begin{array}{l}\text { Türkiye genelinde siyasi partiler arası ittifak yapılması sebebiyle, } \\
\text { oy kullanmadım. }\end{array}$} & 22 & 19 & 41 \\
\hline & $9,1 \%$ & $12,1 \%$ & $10,2 \%$ \\
\hline \multirow{2}{*}{$\begin{array}{l}\text { Türkiye genelinde siyasi partiler arası ittifak yapılması sebebiyle } \\
\text { tepki koyarak başka partilere/başka adaylara oy verdim }\end{array}$} & 42 & 20 & 62 \\
\hline & $17,3 \%$ & $12,7 \%$ & $15,5 \%$ \\
\hline \multirow{2}{*}{$\begin{array}{l}\text { Türkiye genelinde siyasi partiler arası ittifak yapılması sebebiyle } \\
\text { sadece kendi partimin adayını destekledim ve ittifak adayına oy } \\
\text { vermedim }\end{array}$} & 31 & 28 & 59 \\
\hline & $12,8 \%$ & $17,8 \%$ & $14,8 \%$ \\
\hline \multirow{2}{*}{$\begin{array}{l}\text { Türkiye genelinde siyasi partiler arası ittifak yapılması sebebiyle } \\
\text { hem kendi partimin adayını destekledim ve hem de ittifak } \\
\text { adayına oy verdim }\end{array}$} & 51 & 25 & 76 \\
\hline & $21,0 \%$ & $15,9 \%$ & $19,0 \%$ \\
\hline \multirow{2}{*}{$\begin{array}{l}\text { Türkiye genelinde siyasi partiler arası ittifak yapılması sebebiyle, } \\
\text { ittifak partilerin hiçbirine oy vermedim }\end{array}$} & 24 & 3 & 27 \\
\hline & $9,9 \%$ & $1,9 \%$ & $6,8 \%$ \\
\hline \multirow{2}{*}{$\begin{array}{l}\text { Türkiye genelinde siyasi partiler arası ittifak yapılması, oy verme } \\
\text { davranışımı etkilemedi }\end{array}$} & 73 & 62 & 135 \\
\hline & $30,0 \%$ & $39,5 \%$ & $33,8 \%$ \\
\hline \multirow[t]{2}{*}{ Toplam } & 243 & 157 & 400 \\
\hline & $60,8 \%$ & $39,2 \%$ & $100,0 \%$ \\
\hline
\end{tabular}

Notlar $=(i) n=400$, (ii) Pearson $\chi^{2}=16,579^{*} ; \mathrm{p}<.005$, sonuçlar istatistiksel bakımdan anlamlıdır.

Tablo 10 incelendiğinde araştırmaya katılan seçmenlerin "siyasi partilerin seçim ittifakında bulunmaları oy verdiğiniz partiye olan bağlılı̆̆ınızı nasıl etkilemiştir" sorusu ile "cinsiyet değişkeni” arasında istatistikî olarak anlamlı bir ilişki oluştuğu görülmektedir. ( $p=0.005)$. Kadın seçmenler siyasi partilerin ittifak yapması sebebiyle; oy kullanmadığı, sadece kendi partisinin adayını desteklediği ve ittifak adayına oy vermediğini belirtirken; erkek seçmenler ise siyasi partiler arası ittifak yapılması sebebiyle hem kendi parti adayını desteklediği ve hem de ittifak adayına oy verdiğini, tepki koyarak başka partilere oy verdiklerini, siyasi partiler arası ittifak yapılması sebebiyle, ittifak yapan partilerin hiçbirine oy vermediğini beyan etmiştir. Siyasi partiler arası ittifak yapılmasının, erkek seçmenlere oranla kadın seçmenlerin oy verme davranışlarında çok fazla değişiklik yaratmadığının söylenilmesi mümkündür.

Tablo 11. Katılımcıların Eğitim Durumları ve Bir Siyasi Partiye Oy Verirken Etkili Olan Unsurlara Yönelik Algılarının Karşılaştırılması

\begin{tabular}{|c|c|c|c|c|c|c|c|}
\hline \multirow{2}{*}{$\begin{array}{l}\text { Bir siyasi partiye oy } \\
\text { verirken sizin için en } \\
\text { önemli unsur nedir? }\end{array}$} & \multicolumn{7}{|c|}{ Ĕgitim } \\
\hline & İlkokul & Ortaokul & Lise & Önlisans & Lisans & $\begin{array}{l}\text { Yüksek } \\
\text { Lisans }\end{array}$ & Toplam \\
\hline \multirow[t]{2}{*}{ Parti liderinin imajı } & 16 & 3 & 8 & 8 & 5 & 0 & 40 \\
\hline & $24,6 \%$ & $6,1 \%$ & $7,5 \%$ & $8,0 \%$ & $6,8 \%$ & $0 \%$ & $10,0 \%$ \\
\hline \multirow[t]{2}{*}{ Partinin adayları } & 19 & 17 & 24 & 22 & 9 & 0 & 91 \\
\hline & $29,2 \%$ & $34,7 \%$ & $22,6 \%$ & $22,0 \%$ & $12,2 \%$ &, $0 \%$ & $22,8 \%$ \\
\hline \multirow[t]{2}{*}{ Partinin ideolojisi } & 7 & 8 & 19 & 11 & 13 & 2 & 60 \\
\hline & $10,8 \%$ & $16,3 \%$ & $17,9 \%$ & $11,0 \%$ & $17,6 \%$ & $33,3 \%$ & $15,0 \%$ \\
\hline \multirow{2}{*}{$\begin{array}{l}\text { Parti tüzüğü ve parti } \\
\text { programı }\end{array}$} & 4 & 4 & 5 & 4 & 15 & 0 & 32 \\
\hline & $6,2 \%$ & $8,2 \%$ & $4,7 \%$ & $4,0 \%$ & $20,3 \%$ &, $0 \%$ & $8,0 \%$ \\
\hline \multirow[b]{2}{*}{ Partinin projeleri } & 19 & 17 & 50 & 55 & 32 & 4 & 177 \\
\hline & $29,2 \%$ & $34,7 \%$ & $47,2 \%$ & $55,0 \%$ & $43,2 \%$ & $66,7 \%$ & $44,2 \%$ \\
\hline \multirow[t]{2}{*}{ Toplam } & 65 & 49 & 106 & 100 & 74 & 6 & 400 \\
\hline & $16,2 \%$ & $12,2 \%$ & $26,5 \%$ & $25,0 \%$ & $18,5 \%$ & $1,5 \%$ & $100,0 \%$ \\
\hline
\end{tabular}

Notlar $=(i) n=400$, (ii) Pearson $\chi^{2}=56,473^{*} ; \mathrm{p}<.000$, sonuçlar istatistiksel bakımdan anlamlıdır. 
Tablo 11 incelendiğinde araştırmaya katılan seçmenlerin "bir siyasi partiye oy verirken sizin için en önemli unsur" nedir sorusu ile "eğitim değişkeni” arasında istatistikî olarak anlamlı bir ilişki oluştuğu dikkati çekmektedir $(\mathrm{p}=0.000)$. İlkokul mezunu olan katılımcılar için parti liderinin imajı \%24,6, ortaokul mezunları için partinin adayları için \%34,7 oranında etkilidir. Yüksek lisans mezunu olan katılımcılar için partinin ideolojisi ve parti projeleri etkili olarak değerlendirirken; lisans mezunları için parti tüzüğü ve parti programının önemli olduğunu söylenilebilir. Yüksek lisans mezunu katılımcıların \%66,7'sinin parti projelerini en önemli unsur olarak gördüklerini söylemeleri dikkati çeken bir husus olarak değerlendirilebilir.

Tablo 12. Katılımcıların Eğitim Durumları ve Türkiye’de Siyasi Partiler Arası Yapılan Seçim İttifakı Uygulamasının İçeriği Hakkında Bilgi Sahibi Olma Durumlarının Karşılaştırılması

\begin{tabular}{|c|c|c|c|c|c|c|c|}
\hline \multirow{2}{*}{$\begin{array}{l}\text { Türkiye genelinde siyasi } \\
\text { partiler arası yapılan } \\
\text { seçim ittifakı } \\
\text { uygulamasının içeriği } \\
\text { hakkında bilgi sahibi } \\
\text { misiniz? }\end{array}$} & \multicolumn{7}{|c|}{ Ĕgitim } \\
\hline & İlkokul & Ortaokul & Lise & Önlisans & Lisans & $\begin{array}{l}\text { Yüksek } \\
\text { Lisans }\end{array}$ & Toplam \\
\hline \multirow[t]{2}{*}{ Hayır, hiçbir bilgim yok. } & 28 & 17 & 35 & 33 & 9 & 1 & 123 \\
\hline & $43,1 \%$ & $34,7 \%$ & $33,0 \%$ & $33,0 \%$ & $12,2 \%$ & $16,7 \%$ & $30,8 \%$ \\
\hline \multirow{2}{*}{$\begin{array}{l}\text { Siyasi partilerin seçim } \\
\text { ittifakının sadece } \\
\text { varlığından haberdarım }\end{array}$} & 19 & 10 & 17 & 22 & 9 & 0 & 77 \\
\hline & $29,2 \%$ & $20,4 \%$ & $16,0 \%$ & $22,0 \%$ & $12,2 \%$ &, $0 \%$ & $19,2 \%$ \\
\hline \multirow{2}{*}{$\begin{array}{l}\text { Siyasi partilerin seçim } \\
\text { ittifakından haberdarım ve } \\
\text { ittifakların hangi partiler } \\
\text { arasında gerçekleştirildiği } \\
\text { hakkında da bilgi sahibiyim }\end{array}$} & 18 & 22 & 54 & 45 & 56 & 5 & 200 \\
\hline & $27,7 \%$ & $44,9 \%$ & $50,9 \%$ & $45,0 \%$ & $75,7 \%$ & $83,3 \%$ & $50,0 \%$ \\
\hline \multirow[t]{2}{*}{ Toplam } & 65 & 49 & 106 & 100 & 74 & 6 & 400 \\
\hline & $16,2 \%$ & $12,2 \%$ & $26,5 \%$ & $25,0 \%$ & $18,5 \%$ & $1,5 \%$ & $100,0 \%$ \\
\hline
\end{tabular}

Notlar $=(\mathrm{i}) \mathrm{n}=400$, (ii) Pearson $\chi^{2}=38,282^{\mathrm{a}^{*}} ; \mathrm{p}<.000$, sonuçlar istatistiksel bakımdan anlamlıdır.

Tablo 12 incelendiğinde, katılımcıların siyasi partiler arası yapılan seçim ittifakı uygulamasının içeriği hakkında bilgi sahibi olma durumları ile eğitim değişkeni arasında istatistikî olarak anlamlı bir ilişki oluştuğu dikkati çekmektedir ( $\mathrm{p}=0.000$ ). İlkokul mezunlarının siyasi partiler arası yapılan seçim ittifakı uygulamasının içeriği hakkında hiçbir bir bilgiye sahip olmadığı ve siyasi partilerin seçim ittifakının sadece varlığından haberdar oldukları görülürken, yüksek lisans mezunlarının siyasi partilerin seçim ittifakından haberdar oldukları ve ittifakların hangi partiler arasında gerçekleştirildiği hakkında da bilgi sahibi olduklarını görülmektedir. Bu bağlamda eğitim düzeyi yükseldikçe, farkındalık ve bilinç düzeyinin de yükseldiği, bu çerçevece eğitim düzeyi yüksek katılımcıların siyasi partilerin ittifakları ve içeriği konusunda daha fazla bilgi sahibi oldukları altı çizilmesi gereken bir sonuçtur. 
Tablo 13. Katılımcıların Eğitim Durumları ve Türkiye'de Siyasi Partiler Arası İttifak Yapılmasının Oy Verilen Partiye Etkisine Yönelik Algıların Karşılaștırılması

\begin{tabular}{|c|c|c|c|c|c|c|c|}
\hline \multirow{2}{*}{$\begin{array}{l}\text { Türkiye genelinde siyasi } \\
\text { partiler arası ittifak } \\
\text { yapılması oy verdiğiniz } \\
\text { partiyi nasıl etkiledi? }\end{array}$} & \multicolumn{7}{|c|}{ Eğitim } \\
\hline & İlkokul & Ortaokul & Lise & Önlisans & Lisans & $\begin{array}{l}\text { Yüksek } \\
\text { Lisans }\end{array}$ & Toplam \\
\hline \multirow{2}{*}{$\begin{array}{l}\text { Türkiye genelinde siyasi } \\
\text { partiler arası ittifak } \\
\text { yapılmasının, oy verdiğim } \\
\text { parti için faydalı olduğunu } \\
\text { düşünüyorum }\end{array}$} & 17 & 12 & 38 & 30 & 25 & 0 & 122 \\
\hline & $26,6 \%$ & $24,5 \%$ & $\begin{array}{c}35,8 \\
\%\end{array}$ & $30,0 \%$ & $33,8 \%$ &, $0 \%$ & $30,6 \%$ \\
\hline \multirow{2}{*}{$\begin{array}{l}\text { Türkiye genelinde siyasi } \\
\text { partiler arası ittifak } \\
\text { yapılmasının, oy verdiğim } \\
\text { parti için faydalı olmadığını } \\
\text { düşünüyorum. }\end{array}$} & 16 & 22 & 26 & 29 & 20 & 0 & 113 \\
\hline & $25,0 \%$ & $44,9 \%$ & $\begin{array}{c}24,5 \\
\%\end{array}$ & $29,0 \%$ & $27,0 \%$ &, $0 \%$ & $28,3 \%$ \\
\hline \multirow[t]{2}{*}{ Kararsızım } & 31 & 15 & 42 & 41 & 29 & 6 & 164 \\
\hline & $48,4 \%$ & $30,6 \%$ & $\begin{array}{c}39,6 \\
\%\end{array}$ & $41,0 \%$ & $39,2 \%$ & $100,0 \%$ & $100,0 \%$ \\
\hline \multirow[t]{2}{*}{ Toplam } & 64 & 49 & 106 & 100 & 74 & 6 & 400 \\
\hline & $16,0 \%$ & $12,3 \%$ & $\begin{array}{c}26,6 \\
\%\end{array}$ & $25,1 \%$ & $18,5 \%$ & $1,5 \%$ & $100,0 \%$ \\
\hline
\end{tabular}

Notlar $=(i) n=400$, (ii) Pearson $\chi^{2}=18,627^{a^{*}} ; p<, 045$, sonuçlar istatistiksel bakımdan anlamlıdır.

Tablo 13 incelendiğinde, katılımcılara yöneltilen "siyasi partiler arası yapılan seçim ittifakının oy verdiğiniz partiyi etkileme durumu" sorusu ile "eğitim değişkeni” arasında istatistikî olarak anlamlı bir ilişki oluştuğu tespit edilmiştir ( $\mathrm{p}=0.045)$. Lise mezunu katılımcıların \%35,8'i siyasi partiler arası ittifak yapılmasının, oy verdiği parti için faydalı olduğunu düşünmektedirler. Ortaokul mezunu katılımcıların \%44,9'u ise siyasi partiler arası ittifak yapılmasının, oy verdiği parti için faydalı olmadığı yönünde görüş belirtmişlerdir. Yüksek lisans mezunu katılımcıların tamamının siyasi partiler arası ittifak yapılmasının, oy verdiği parti için faydalı olduğu konusunda kararsız olduğu görülmektedir. Bu bağlamda yüksek eğitimlilerde kararsızlığın olması siyasi parti ittifakının eğitim düzeyi yüksek seçmenler için yeterli ölçüde ikna edici olmadığının gösterdiği yönünde çıkarımda bulunulabilir.

Tablo 14. Katılımcıların Yaşları ve Bir Siyasi Partiye Oy Verirken Etkili Olan Unsurlara Yönelik Algılarının Karşılaştırılması

\begin{tabular}{|c|c|c|c|c|c|c|}
\hline \multirow{2}{*}{$\begin{array}{l}\text { Bir siyasi partiye oy } \\
\text { verirken sizin için en } \\
\text { önemli unsur nedir? }\end{array}$} & \multicolumn{6}{|c|}{ Yaş } \\
\hline & $18-28$ & 29-39 & $40-50$ & $51-61$ & 62 ve üstü & Toplam \\
\hline \multirow[t]{2}{*}{ Parti liderinin imaj1 } & 8 & 3 & 14 & 6 & 9 & 40 \\
\hline & $7,4 \%$ & $2,1 \%$ & $13,5 \%$ & $20,7 \%$ & $47,4 \%$ & $10,0 \%$ \\
\hline \multirow[t]{2}{*}{ Partinin adayları } & 18 & 35 & 24 & 6 & 8 & 91 \\
\hline & $16,7 \%$ & $25,0 \%$ & $23,1 \%$ & $20,7 \%$ & $42,1 \%$ & $22,8 \%$ \\
\hline \multirow[t]{2}{*}{ Partinin ideolojisi } & 22 & 22 & 14 & 2 & 0 & 60 \\
\hline & $20,4 \%$ & $15,7 \%$ & $13,5 \%$ & $6,9 \%$ &, $0 \%$ & $15,0 \%$ \\
\hline \multirow{2}{*}{$\begin{array}{l}\text { Parti tüzüğü ve parti } \\
\text { programı }\end{array}$} & 6 & 13 & 9 & 4 & 0 & 32 \\
\hline & $5,6 \%$ & $9,3 \%$ & $8,7 \%$ & $13,8 \%$ &, $0 \%$ & $8,0 \%$ \\
\hline \multirow[b]{2}{*}{ Partinin projeleri } & 54 & 67 & 43 & 11 & 2 & 177 \\
\hline & $50,0 \%$ & $47,9 \%$ & $41,3 \%$ & $37,9 \%$ & $10,5 \%$ & $44,2 \%$ \\
\hline \multirow[t]{2}{*}{ Toplam } & 108 & 140 & 104 & 29 & 19 & 400 \\
\hline & $27,0 \%$ & $35,0 \%$ & $26,0 \%$ & $7,2 \%$ & $4,8 \%$ & $100,0 \%$ \\
\hline
\end{tabular}

Notlar $=\left(\right.$ i) $n=400$, (ii) Pearson $\chi^{2}=62,574^{*} ; \mathrm{p}<, 000$, sonuçlar istatistiksel bakımdan anlamlıdır 
Tablo 14 incelendiğinde, katılımcılara yöneltilen "bir siyasi partiye oy verirken sizin için en önemli unsur nedir” sorusuna verdikleri cevaplar ile yaş değişkeni arasında istatistikî olarak anlamlı bir ilişki oluştuğu tespit edilmiştir $(\mathrm{p}=0.000)$. 62 ve üstü yaş grubu seçmenler parti lideri imajı ve parti adaylarının oy vermelerinde en önemli unsur olarak görmektedir. 18-28 yaş grubu seçmenler için parti ideolojisi ve parti projeleri oy vermelerinde önemli unsur teşkil ederken; 51-61 yaş grubu seçmenler için parti tüzüğü ve parti programının oy vermelerinde önemli unsur olduğunun söylenilmesi mümkündür. Bu bağlamda 18-28 yaş grubu seçmenlerin yarısının oy vermelerinde en önemli unsurun parti projelerinin olduğu yönünde çıkarımda bulunulabilir.

Tablo 15. Katılımcıların Yaşları ve Türkiye’de Siyasi Partiler Arası Yapılan Seçim İttifakı Uygulamasının İçeriği Hakkında Bilgi Sahibi Olma Durumlarının Karşılaştırılması

\begin{tabular}{|c|c|c|c|c|c|c|}
\hline \multirow{2}{*}{$\begin{array}{c}\text { Türkiye genelinde siyasi } \\
\text { partiler arası yapılan } \\
\text { seçim ittifakı } \\
\text { uygulamasının içeriği } \\
\text { hakkında bilgi sahibi } \\
\text { misiniz? }\end{array}$} & \multicolumn{6}{|c|}{ Yaș } \\
\hline & $18-28$ & 29-39 & $40-50$ & $51-61$ & $\begin{array}{l}62 \text { ve } \\
\text { üsttü }\end{array}$ & Toplam \\
\hline \multirow[t]{2}{*}{ Hayır, hiçbir bilgim yok. } & 44 & 37 & 24 & 10 & 8 & 123 \\
\hline & $40,7 \%$ & $26,4 \%$ & $23,1 \%$ & $34,5 \%$ & $42,1 \%$ & $30,8 \%$ \\
\hline \multirow{2}{*}{$\begin{array}{l}\text { Siyasi partilerin seçim } \\
\text { ittifakının sadece } \\
\text { varlığından haberdarım }\end{array}$} & 29 & 26 & 11 & 7 & 4 & 77 \\
\hline & $26,9 \%$ & $18,6 \%$ & $10,6 \%$ & $24,1 \%$ & $21,1 \%$ & $19,2 \%$ \\
\hline \multirow{2}{*}{$\begin{array}{l}\text { Siyasi partilerin seçim } \\
\text { ittifakından haberdarım ve } \\
\text { ittifakların hangi partiler } \\
\text { arasında gerçekleştirildiği } \\
\text { hakkında da bilgi sahibiyim }\end{array}$} & 35 & 77 & 69 & 12 & 7 & 200 \\
\hline & $32,4 \%$ & $55,0 \%$ & $66,3 \%$ & $41,4 \%$ & $36,8 \%$ & $50,0 \%$ \\
\hline \multirow[t]{2}{*}{ Toplam } & 108 & 140 & 104 & 29 & 19 & 400 \\
\hline & $27,0 \%$ & $35,0 \%$ & $26,0 \%$ & $7,2 \%$ & $4,8 \%$ & $100,0 \%$ \\
\hline
\end{tabular}

Notlar $=\left(\right.$ i) $n=400$, (ii) Pearson $\chi^{2}=29,039^{*} ; \mathrm{p}<.000$, sonuçlar istatistiksel bakımdan anlamlıdır

Tablo 15 incelendiğinde, katılımcıların siyasi partiler arası yapılan seçim ittifakı uygulamasının içeriği hakkında bilgi sahibi olma durumları ile yaş değişkeni arasında istatistikî olarak anlamlı bir ilişki oluştuğu görülmüştür ( $\mathrm{p}=0.000$ ). 62 ve üstü yaş grubu seçmenlerin, siyasi partiler arası yapılan seçim ittifakı uygulamasının içeriği hakkında yeterince bilgi sahibi olmadığı dikkati çekmektedir. 40-50 yaş grubu seçmenlerin ise siyasi partilerin seçim ittifakından haberdar oldukları ve ittifakların hangi partiler arasında gerçekleştirildiği hakkında da yeterince bilgi sahibi oldukları (\% 66,3) görülmektedir. Bu bağlamda orta yaş seçmenlerin siyasi konulara olan ilgilerinin daha yüksek olduğu ve siyasi gündemi takip ettiklerini yönünde çıkarımda bulunulabilir. 
Tablo 16. Katılımcıların Yaşları ve Türkiye'de Siyasi Partiler Arası İttifak Yapılmasının Oy Verilen Partiye Etkisine Yönelik Algıların Karşılaştırılması

\begin{tabular}{|c|c|c|c|c|c|c|}
\hline \multirow{2}{*}{$\begin{array}{l}\text { Siyasi partilerin seçim } \\
\text { ittifakında bulunmaları oy } \\
\text { verdiğiniz partiye olan } \\
\text { bağlı̆ığınızı nasıl etkiledi? }\end{array}$} & \multicolumn{6}{|c|}{ Yaş } \\
\hline & $18-28$ & 29-39 & $40-50$ & $51-61$ & $\begin{array}{l}62 \text { ve } \\
\text { üstü }\end{array}$ & Toplam \\
\hline \multirow{2}{*}{$\begin{array}{l}\text { Türkiye genelinde siyasi partiler } \\
\text { arasi ittifak yapılması sebebiyle, } \\
\text { oy kullanmadım. }\end{array}$} & 21 & 9 & 8 & 2 & 1 & 41 \\
\hline & $19,4 \%$ & $6,4 \%$ & $7,7 \%$ & $6,9 \%$ & $5,3 \%$ & $10,2 \%$ \\
\hline \multirow{2}{*}{$\begin{array}{l}\text { Türkiye genelinde siyasi partiler } \\
\text { arası ittifak yapılması sebebiyle } \\
\text { tepki koyarak başka } \\
\text { partilere/başka adaylara oy verdim }\end{array}$} & 16 & 30 & 12 & 4 & 0 & 62 \\
\hline & $14,8 \%$ & $21,4 \%$ & $11,5 \%$ & $13,8 \%$ &, $0 \%$ & $15,5 \%$ \\
\hline \multirow{2}{*}{$\begin{array}{l}\text { Türkiye genelinde siyasi partiler } \\
\text { arası ittifak yapılması sebebiyle } \\
\text { sadece kendi partimin adayını } \\
\text { destekledim ve ittifak adayına oy } \\
\text { vermedim }\end{array}$} & 16 & 15 & 18 & 4 & 6 & 59 \\
\hline & $14,8 \%$ & $10,7 \%$ & $17,3 \%$ & $13,8 \%$ & $31,6 \%$ & $14,8 \%$ \\
\hline \multirow{2}{*}{$\begin{array}{l}\text { Türkiye genelinde siyasi partiler } \\
\text { arası ittifak yapılması sebebiyle } \\
\text { hem kendi partimin adayını } \\
\text { destekledim ve hem de ittifak } \\
\text { adayına oy verdim }\end{array}$} & 9 & 33 & 24 & 6 & 4 & 76 \\
\hline & $8,3 \%$ & $23,6 \%$ & $23,1 \%$ & $20,7 \%$ & $21,1 \%$ & $19,0 \%$ \\
\hline \multirow{2}{*}{$\begin{array}{l}\text { Türkiye genelinde siyasi partiler } \\
\text { arası ittifak yapılması sebebiyle, } \\
\text { ittifak partilerin hiçbirine oy } \\
\text { vermedim }\end{array}$} & 7 & 6 & 6 & 4 & 4 & 27 \\
\hline & $6,5 \%$ & $4,3 \%$ & $5,8 \%$ & $13,8 \%$ & $21,1 \%$ & $6,8 \%$ \\
\hline \multirow{2}{*}{$\begin{array}{l}\text { Türkiye genelinde siyasi partiler } \\
\text { arası ittifak yapılması, oy verme } \\
\text { davranıșımı etkilemedi }\end{array}$} & 39 & 47 & 36 & 9 & 4 & 135 \\
\hline & $36,1 \%$ & $33,6 \%$ & $34,6 \%$ & $31,0 \%$ & $21,1 \%$ & $33,8 \%$ \\
\hline \multirow[t]{2}{*}{ Toplam } & 108 & 140 & 104 & 29 & 19 & 400 \\
\hline & $27,0 \%$ & $35,0 \%$ & $26,0 \%$ & $7,2 \%$ & $4,8 \%$ & $100,0 \%$ \\
\hline
\end{tabular}

Notlar $=(i) n=400$, (ii) Pearson $\chi^{2}=44,763^{*} ; \mathrm{p}<, 001$, sonuçlar istatistiksel bakımdan anlamlıdır.

Tablo 16 incelendiğinde, katılımcılara yöneltilen "siyasi partilerin seçim ittifakında bulunmaları oy verdiğiniz partiye olan bağlılığınızı nasıl etkiledi” sorusuna verilen cevaplar ile yaş değişkeni arasında istatistikî olarak anlamlı bir ilişki oluştuğu tespit edilmiştir ( $\mathrm{p}=0.001)$. 18-28 yaş grubu seçmenlerin siyasi partiler arası ittifak yapılması sebebiyle, oy kullanmadığı yönünde daha fazla görüş bildirmişlerdir. 29-39 yaş grubu seçmenler arasında, siyasi partiler arası ittifak yapılması sebebiyle tepki koyarak başka partilere/başka adaylara oy verdikleri görüşü daha fazla yer tutmaktadır. 62 ve üstü yaş grubu seçmenlerin görüşlerinin ise, siyasi partiler arası ittifak yapılması sebebiyle sadece kendi parti adayını desteklediği ve ittifak adayına oy vermediği ve siyasi partiler arası ittifak yapılması sebebiyle, ittifak partilerin hiçbirine oy vermediği yönünde yoğunlaşmıştır. Bu bağlamda genç grup seçmenlerin (18-28 yaş grubu seçmenlerin) \%36,1'inde siyasi partiler arası ittifak yapılmasının, oy verme davranışlarında değişiklik yaratmadığı görüşü hakim olmuştur. 
Tablo 17. Katılımcıların Gelir Durumları ve Türkiye’de Siyasi Partiler Arası Yapılan Seçim İttifakı Uygulamasının İçeriği Hakkında Bilgi Sahibi Olma Durumlarının Karşılaştırılması

\begin{tabular}{|c|c|c|c|c|c|c|c|}
\hline \multirow{2}{*}{$\begin{array}{l}\text { Türkiye genelinde siyasi partiler } \\
\text { arası yapılan seçim ittifakı } \\
\text { uygulamasının içeriği hakkında } \\
\text { bilgi sahibi misiniz? }\end{array}$} & \multicolumn{7}{|c|}{ Geliriniz } \\
\hline & $\stackrel{8}{\Xi}$ & : & ن & ل1 & 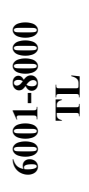 & $\frac{8}{8}$ & $\begin{array}{c}\text { Topla } \\
\text { m }\end{array}$ \\
\hline \multirow[t]{2}{*}{ Hayır, hiçbir bilgim yok. } & 36 & 23 & 54 & 8 & 1 & 1 & 123 \\
\hline & $\begin{array}{c}40,9 \\
\%\end{array}$ & $\begin{array}{c}39,0 \\
\%\end{array}$ & $\begin{array}{c}34,8 \\
\%\end{array}$ & $\begin{array}{c}11,8 \\
\%\end{array}$ & $4,0 \%$ & $\begin{array}{c}20,0 \\
\%\end{array}$ & $30,8 \%$ \\
\hline \multirow{2}{*}{$\begin{array}{l}\text { Siyasi partilerin seçim ittifakının } \\
\text { sadece varlığından haberdarım }\end{array}$} & 21 & 17 & 20 & 16 & 3 & 0 & 77 \\
\hline & $\begin{array}{c}23,9 \\
\%\end{array}$ & $\begin{array}{c}28,8 \\
\%\end{array}$ & $\begin{array}{c}12,9 \\
\%\end{array}$ & $\begin{array}{c}23,5 \\
\%\end{array}$ & $\begin{array}{c}12,0 \\
\%\end{array}$ &, $0 \%$ & $19,2 \%$ \\
\hline \multirow{2}{*}{$\begin{array}{l}\text { Siyasi partilerin seçim ittifakından } \\
\text { haberdarım ve ittifakların hangi } \\
\text { partiler arasında gerçekleştirildiği } \\
\text { hakkında da bilgi sahibivim }\end{array}$} & 31 & 19 & 81 & 44 & 21 & 4 & 200 \\
\hline & $\begin{array}{c}35,2 \\
\%\end{array}$ & $\begin{array}{c}32,2 \\
\%\end{array}$ & $\begin{array}{c}52,3 \\
\%\end{array}$ & $\begin{array}{l}64,7 \\
\%\end{array}$ & $\begin{array}{c}84,0 \\
\%\end{array}$ & $\begin{array}{l}80,0 \\
\%\end{array}$ & $50,0 \%$ \\
\hline \multirow[t]{2}{*}{ Toplam } & 88 & 59 & 155 & 68 & 25 & 5 & 400 \\
\hline & $\begin{array}{c}22,0 \\
\%\end{array}$ & $\begin{array}{c}14,8 \\
\%\end{array}$ & $\begin{array}{c}38,8 \\
\%\end{array}$ & $\begin{array}{c}17,0 \\
\%\end{array}$ & $6,2 \%$ & $1,2 \%$ & $\begin{array}{c}100,0 \\
\%\end{array}$ \\
\hline
\end{tabular}

Notlar= (i) $n=400$, (ii) Pearson $\chi^{2}=45,742^{*} ; \mathrm{p}<.000$, sonuçlar istatistiksel bakımdan anlamlıdır.

Tablo 17 incelendiğinde, katılımcıların siyasi partiler arası yapılan seçim ittifakı uygulamasının içeriği hakkında bilgi sahibi olma durumları ile gelir durumları arasında istatistikî olarak anlamlı bir ilişki oluştuğu dikkati çekmektedir ( $\mathrm{p}=0.000)$. 1000 TL altı gelire sahip seçmenlerin \% 40,9'unun seçim ittifakı uygulamasının içeriği hakkında hiçbir bir bilgi sahibi olmadığını, 1001-2000 TL gelire sahip seçmenlerin \% 28,8'inin siyasi partiler arası yapılan seçim ittifakının sadece varlığından haberdar olduğunu, 8001-10000 TL gelire sahip seçmenlerin ise \% 80'inin hem siyasi partilerin seçim ittifakından haberdar oldukları hem de ittifakların hangi partiler arasında gerçekleştirildiği yönünde bilgi sahibi oldukları görülmektedir. Bu bağlamda düşük gelire sahip olanların siyasi partiler arası yapılan seçim ittifakı uygulamasının içeriği hakkında yeterince bilgi sahibi olmadıklarını, yüksek gelire sahip seçmenlerin siyasi partilerin seçim ittifakından haberdar oldukları ve ittifakların hangi partiler arasında gerçekleştirildiği konusunda yeterince bilgi sahibi olduklarını söylenilmesi mümkündür. 
Tablo 18. Katılımcıların Gelir Durumları ve Türkiye'de Siyasi Partiler Arası İttifak Yapılması Seçmenlerin Oy Verdiği Partiye Olan Bağlılı̆̆ını Etkileme Durumunun Karşılaştırılması

\begin{tabular}{|c|c|c|c|c|c|c|c|}
\hline \multirow{2}{*}{$\begin{array}{l}\text { Siyasi partilerin seçim ittifakında } \\
\text { bulunmaları oy verdiğiniz partiye } \\
\text { olan bağlığınızı nasıl etkiledi? }\end{array}$} & \multicolumn{7}{|c|}{ Geliriniz } \\
\hline & 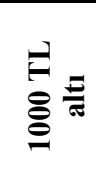 & 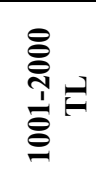 & 离 & 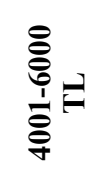 & 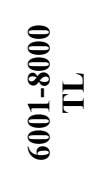 & 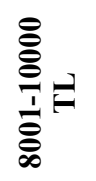 & Toplam \\
\hline \multirow{2}{*}{$\begin{array}{l}\text { Geliriniz Türkiye genelinde siyasi } \\
\text { partiler arası ittifak yapılması } \\
\text { sebebiyle, oy kullanmadım. }\end{array}$} & 18 & 8 & 9 & 4 & 1 & 1 & 41 \\
\hline & $20,5 \%$ & $13,6 \%$ & $5,8 \%$ & $5,9 \%$ & $4,0 \%$ & $20,0 \%$ & $10,2 \%$ \\
\hline \multirow{2}{*}{$\begin{array}{l}\text { Türkiye genelinde siyasi partiler } \\
\text { arası ittifak yapılması sebebiyle } \\
\text { tepki koyarak başka partilere/başka } \\
\text { adaylara oy verdim }\end{array}$} & 9 & 15 & 22 & 14 & 1 & 1 & 62 \\
\hline & $10,2 \%$ & $25,4 \%$ & $14,2 \%$ & $20,6 \%$ & $4,0 \%$ & $20,0 \%$ & $15,5 \%$ \\
\hline \multirow{2}{*}{$\begin{array}{l}\text { Türkiye genelinde siyasi partiler } \\
\text { arası ittifak yapılması sebebiyle } \\
\text { sadece kendi partimin adayını } \\
\text { destekledim ve ittifak adayına oy } \\
\text { vermedim }\end{array}$} & 15 & 9 & 23 & 10 & 2 & 0 & 59 \\
\hline & $17,0 \%$ & $15,3 \%$ & $14,8 \%$ & $14,7 \%$ & $8,0 \%$ &, $0 \%$ & $14,8 \%$ \\
\hline \multirow{2}{*}{$\begin{array}{l}\text { Türkiye genelinde siyasi partiler } \\
\text { arası ittifak yapılması sebebiyle } \\
\text { hem kendi partimin adayını } \\
\text { destekledim ve hem de ittifak } \\
\text { adayına oy verdim }\end{array}$} & 8 & 8 & 29 & 19 & 10 & 2 & 76 \\
\hline & $9,1 \%$ & $13,6 \%$ & $18,7 \%$ & $27,9 \%$ & $40,0 \%$ & $40,0 \%$ & $19,0 \%$ \\
\hline \multirow{2}{*}{$\begin{array}{l}\text { Türkiye genelinde siyasi partiler } \\
\text { arası ittifak yapılması sebebiyle, } \\
\text { ittifak partilerin hiçbirine oy } \\
\text { vermedim }\end{array}$} & 6 & 4 & 9 & 4 & 4 & 0 & 27 \\
\hline & $6,8 \%$ & $6,8 \%$ & $5,8 \%$ & $5,9 \%$ & $16,0 \%$ &, $0 \%$ & $6,8 \%$ \\
\hline \multirow{2}{*}{$\begin{array}{l}\text { Türkiye genelinde siyasi partiler } \\
\text { arası ittifak yapılması, oy verme } \\
\text { davranışımı etkilemedi }\end{array}$} & 32 & 15 & 63 & 17 & 7 & 1 & 135 \\
\hline & $36,4 \%$ & $25,4 \%$ & $40,6 \%$ & $25,0 \%$ & $28,0 \%$ & $20,0 \%$ & $33,8 \%$ \\
\hline \multirow[t]{2}{*}{ Toplam } & 88 & 59 & 155 & 68 & 25 & 5 & 400 \\
\hline & $22,0 \%$ & $14,8 \%$ & $38,8 \%$ & $17,0 \%$ & $6,2 \%$ & $1,2 \%$ & $100,0 \%$ \\
\hline
\end{tabular}

Notlar $=\left(\right.$ i) $n=400$, (ii) Pearson $\chi^{2}=50,632^{*} ; \mathrm{p}<.002$, sonuçlar istatistiksel bakımdan anlamlıdır

Tablo 18 incelendiğinde, katılımcılara yöneltilen "siyasi partilerin seçim ittifakında bulunmaları oy verdiğiniz partiye olan bağlılığı nasıl etkiledi” sorusuna verdikleri yanıtlar ile gelir değişkeni arasında istatistikî olarak anlamlı bir ilişki oluştuğu yönünde sonuç elde edilmiştir ( $\mathrm{p}=0.002$ ). 1000 TL altı gelir grubuna sahip seçmenlerin görüşleri siyasi partiler arası ittifak yapılması sebebiyle, oy kullanmadığı ve siyasi partiler arası ittifak yapılması sebebiyle sadece kendi parti adayını desteklediği ve ittifak adayına oy vermediğini yönünde şekillenmiştir. 1001-2000 TL arası gelire sahip seçmenlerin \% 25,4'ü siyasi partiler arası ittifak yapılması sebebiyle tepki koyarak başka partilere/başka adaylara oy verdiklerini beyan etmişlerdir. 6001-8000 TL ve 8001-10000 TL gelire sahip seçmenlerin görüşlerinin çoğunluğunun "siyasi partiler arası ittifak yapılması sebebiyle sadece kendi parti adayını destekleme ve ittifak adayına oy verme” yönünde oluştuğu görülmektedir. 2001-4000 TL gelire sahip seçmenlerin \%40,6'sının ise siyasi partiler arası ittifak yapılmasının, oy verme davranışlarını etkilemediği görüşündedir. Bu bağlamda siyasi partiler arası ittifak yapılmasının orta gelirli seçmenlerin oy verme davranışlarında yeterince değişiklik yaratmadığı söylenilebilir. 


\section{Siyasi Partiler Arası İttifak Uygulamalarının Seçmenlerin Oy Verme Davranışı Üzerindeki Etkilerine Yönelik Seçmen Algıları}

Çalışmanın bu kısmında, siyasi partiler arasında gerçekleştirilen ittifak uygulamalarının, seçmenlerin oy verme davranışı üzerindeki etkilerine yönelik algılarını tespit edebilmek adına 13 önerme verilmiş, katılımcılardan bu önermelere katılma düzeylerini (1 kesinlikle katılmiyorum'dan-5 kesinlikle katılıyorum'a kadar) belirtmeleri istenmiştir. Tablo 20 analiz edilirken kullanılmak amacıyla, 5'li likert dereceleme ölçeğine uygun olarak puan aralığı hesaplanmış ve puan aralığı "0,80" olarak bulunmuştur ${ }^{4}$. Bu hesaplamaya göre değerlendirme aralıkları Tablo 19'de gösterilmiştir (Usta ve Bilgiç, 2017, s.241).

Tablo 19. 5'li Likert Ölçeğine Göre Puan Aralıkları

\begin{tabular}{|l|l|l|}
\hline & Puan Aralıkları & Seçenekler \\
\hline $\mathbf{1}$ & $1,00-1,80$ & Kesinlikle Katılmıyorum \\
\hline $\mathbf{2}$ & $1,81-2,60$ & Katılmıorum \\
\hline $\mathbf{3}$ & $2,61-3,40$ & Kararsizım \\
\hline $\mathbf{4}$ & $3,41-4,20$ & Katıliyorum \\
\hline $\mathbf{5}$ & $4,21-5,00$ & Kesinlikle Kat1liyorum \\
\hline
\end{tabular}

Betimleyici/tanımlayıcı (descriptive) analiz tekniğiyle değerlendirmeye tabi tutulan önermeler ve elde edilen bulgular aşağıdaki tabloda gösterilmiştir.

Tablo 20. Türkiye’de Siyasi Partilerin İttifak Yapmasının Seçmenlerin Oy Verme Davranışı Üzerinde Etkileri Konusunda Görüşleri

\begin{tabular}{|c|c|c|c|c|}
\hline Önermeler & $\mathbf{N}$ & Ort. & Std. Sp. & Katılma Düz \\
\hline $\begin{array}{l}\text { Yazılı ve görsel medya ittifak içinde olan partilerin söylem, } \\
\text { aday ve projelerini tanımamızda etkili olmusstur }\end{array}$ & 400 & 3,6825 & 1,13795 & Kat1lyyorum \\
\hline $\begin{array}{l}\text { Seçim döneminde ittifaklar yazılı ve görsel medya } \\
\text { açısından önemli gündem olmuştur }\end{array}$ & 400 & 3,6050 & 1,06856 & Katıliyorum \\
\hline $\begin{array}{l}\text { Önümüzdeki siyasi süreçte hiçbir partinin tek başına iktidar } \\
\text { olma şansı yoktur }\end{array}$ & 400 & 3,5675 & 1,15054 & Kat1liyorum \\
\hline $\begin{array}{l}\text { Sosyal medya, ittifak içinde olan partilerin söylem, aday ve } \\
\text { projelerini tanımamızda etkili olmuștur }\end{array}$ & 400 & 3,5525 & 1,09327 & Kat1liyorum \\
\hline $\begin{array}{l}\text { Seçim süreci içerisinde siyasi partilerin ittifak haberleri } \\
\text { çeşitli kitle iletişim araçlarında yapılan siyasi kampanyalar } \\
\text { siyasal tercihimde etkili olmuștur }\end{array}$ & 400 & 3,5250 & 1,15226 & Katıliyorum \\
\hline İttifaklar siyasi partilerin baraj kaygılarından doğmuștur & 400 & 3,3500 & 1,13389 & Kararsızım \\
\hline $\begin{array}{l}\text { Siyasi partiler arası ittifak yapılması, ittifakı oluşturan } \\
\text { siyasi partilerin çıkarları için kurulmuștur }\end{array}$ & 400 & 3,2200 & 1,16404 & Kararsızım \\
\hline $\begin{array}{l}\text { Siyasi partiler arası ittifakların devam etmesi gerektiğini } \\
\text { düşünüyorum }\end{array}$ & 400 & 2,9750 & 1,16953 & Kararsızım \\
\hline $\begin{array}{l}\text { Cumhurbaşkanllğı Hükümet Sistemi partileri ittifak } \\
\text { kurmaya yöneltmiștir }\end{array}$ & 400 & 2,9400 & 1,20625 & Kararsızım \\
\hline Partilerin ittifak yapması yeni bir siyaset modelidir & 400 & 2,9250 & 1,16738 & Kararsızım \\
\hline $\begin{array}{l}\text { Siyasi partiler arası ittifak yapıılması oy verme } \\
\text { davranışımda değișiklik yaratmıştır }\end{array}$ & 400 & 2,8425 & 1,36284 & Kararsızım \\
\hline $\begin{array}{l}\text { Dış politikadan kaynaklı sorunları çözmek için ittifak } \\
\text { kurulmuştur }\end{array}$ & 400 & 2,3750 & 1,12808 & Katılmiyorum \\
\hline Terör sorununu çözmek için ittifak kurulmuștur & 400 & 2,3150 & 1,19765 & Katılmiyorum \\
\hline
\end{tabular}

Derece: $1=$ Hiç Katılmıyorum, 5= Kesinlikle katılıyorum

\footnotetext{
${ }^{4}$ (En yüksek değer - en düşük değer)/Seçenek sayısı (5-1)/5=0,80
} 
Tablo 20'de görüleceği üzere, Yazılı ve görsel medya ile birlikte sosyal medyanın da ittifak içinde olan partilerin söylemlerinin, aday ve projelerini tanımada etkili olduğu, seçim döneminde ittifakların yazılı ve görsel medya açısında önemli gündem olduğu şeklindeki önermelere seçmenlerin önemli bir kısmı katıldıklarını beyan etmiştir. "Seçim süreci içerisinde siyasi partilerin ittifak haberleri çeşitli kitle iletişim araçlarında yapılan siyasi kampanyalar siyasal tercihimde etkili olmuştur” ve “önümüzdeki siyasi süreçte hiçbir partinin tek başına iktidar olma şansı yoktur” önermelerine de seçmenler katıldıkları yönünde ifade de bulunmuştur.

“İttifaklar siyasi partilerin baraj kaygılarından doğmuştur”, "siyasi partiler arası ittifak yapılması, ittifakı oluşturan siyasi partilerin çıkarları için kurulmuştur” önermeleri noktasında kararsız kaldıkları söylenilebilir. Bununla birlikte, "siyasi partiler arası ittifak yapılmasının yeni bir siyaset modeli olduğu" konusunda net bir fikir birliği oluşmamıştır. Katılımcılar, "siyasi partiler arası ittifakların devam etmesi gerektiği” konusunda da kararsız kalmışlardır. Son olarak, "siyasi partiler arası ittifak yapılması oy verme davranışımda değişiklik yaratmıştır" ifadesine katılan kadar ve katılmayan seçmenlerin de yer alması bu konuda da görüş birliğinin oluşmadığını göstermektedir.

"Dış politikadan kaynaklı sorunları çözmek için ittifak kurulmuştur" ve "terör sorununu çözmek için ittifak kurulmuştur” önermelerine yönelik seçmenler katılmadıkları yönünde görüş bildirmişlerdir. Siyasi partiler arası ittifakın "dış politikadan kaynaklı sorunları ve terör sorunlarını çözmek için kurulmadığı" yönünde katılımcıların görüş beyan etmesi, Tablo 20'nin en dikkat çekici bulgusu olarak değerlendirilebilir.

Tablo 21. Türkiye'de Siyasi Partilerin İttifak Yapması Hakkında Seçmenlerin Görüşleri ile Cinsiyet Değişkeni Arasındaki İlişkiye Yönelik T Testi

\begin{tabular}{|c|c|c|c|c|c|c|}
\hline \multirow[t]{2}{*}{$\begin{array}{l}\text { Türkiye'de siyasi partilerin ittifak yapmasının } \\
\text { seçmenlerin oy verme davranışı üzerinde etkileri } \\
\text { konusunda görüşleri }\end{array}$} & \multicolumn{2}{|c|}{$\begin{array}{c}\text { Erkek } \\
(\mathrm{n}=\mathbf{2 4 3})\end{array}$} & \multicolumn{2}{|c|}{$\operatorname{Kadın}(n=157)$} & \multicolumn{2}{|c|}{$\begin{array}{l}\text { Bağımlı İki } \\
\text { Grup t Testi }\end{array}$} \\
\hline & Ort . & Ss. & Ort. & Ss. & $\mathbf{T}$ & $\mathbf{p}$ \\
\hline $\begin{array}{l}\text { Siyasi partiler arası ittifak yapılması oy verme } \\
\text { davranışımda değişiklik yaratmıștır }\end{array}$ & 2,82 & 1,39 & 2,86 & 1,31 & 0,280 & 0,780 \\
\hline $\begin{array}{l}\text { Cumhurbaşkanlığ } 1 \text { Hükümet Sistemi partileri ittifak } \\
\text { kurmaya yöneltmiștir }\end{array}$ & 2,76 & 1,22 & 3,21 & 1,12 & 3,745 & 0,000 \\
\hline $\begin{array}{l}\text { Dış politikadan kaynaklı sorunları çözmek için } \\
\text { ittifak kurulmuştur }\end{array}$ & 2,39 & 1,12 & 2,33 & 1,13 & 0,533 & 0,594 \\
\hline Terör sorununu çözmek için ittifak kurulmuştur & 2,42 & 1,21 & 2,14 & 1,14 & 2,361 & 0,019 \\
\hline Partilerin ittifak yapmas1 yeni bir siyaset modelidir & 2,74 & 1,17 & 3,19 & 1,10 & 3,815 & 0,000 \\
\hline $\begin{array}{l}\text { Siyasi partiler aras1 ittifak yapılmas1, ittifak1 } \\
\text { olușturan siyasi partilerin ç1karları için kurulmuștur }\end{array}$ & 3,03 & 1,20 & 3,50 & 1,04 & 3,983 & 0,000 \\
\hline $\begin{array}{l}\text { Sosyal medya, ittifak içinde olan partilerin söylem, } \\
\text { aday ve projelerini tanımamızda etkili olmuştur }\end{array}$ & 3,41 & 1,17 & 3,77 & 0,91 & 3,247 & 0,001 \\
\hline $\begin{array}{l}\text { İttifaklar siyasi partilerin baraj kaygılarından } \\
\text { doğmuștur }\end{array}$ & 3,34 & 1,18 & 3,35 & 1,04 & 0,005 & 0,996 \\
\hline $\begin{array}{l}\text { Önümüzdeki siyasi süreçte hiçbir partinin tek başına } \\
\text { iktidar olma şansı yoktur }\end{array}$ & 3,50 & 1,20 & 3,66 & 1,05 & 1,328 & 0,185 \\
\hline $\begin{array}{l}\text { Seçim döneminde ittifaklar yazılı ve görsel medya } \\
\text { açısından önemli gündem olmuștur }\end{array}$ & 3,41 & 1,13 & 3,89 & 0,87 & 4,515 & 0,000 \\
\hline $\begin{array}{l}\text { Seçim süreci içerisinde siyasi partilerin ittifak } \\
\text { haberleri çeşitli kitle iletişim araçlarında yapılan } \\
\text { siyasi kampanyalar siyasal tercihimde etkili olmuştu }\end{array}$ & 3,39 & 1,16 & 3,71 & 1,10 & 2,739 & 0,006 \\
\hline $\begin{array}{l}\text { Siyasi partiler arası ittifakların devam etmesi } \\
\text { gerektiğini düșünüyorum }\end{array}$ & 2,96 & 1,16 & 2,98 & 1,18 & 0,168 & 0,866 \\
\hline $\begin{array}{l}\text { Yazılı ve görsel medya ittifak içinde olan partilerin } \\
\text { söylem, aday ve projelerini tanımamızda etkili } \\
\text { olmuștur }\end{array}$ & 3,54 & 1,23 & 3,89 & 0,93 & 3,078 & 0,002 \\
\hline
\end{tabular}


Tablo 21 incelendiğinde, Türkiye'de siyasi partilerin ittifak yapması hakkında seçmenlerin görüşleri ile cinsiyet değişkeni arasındaki ilişki karşılaştırıldığında, istatistikî olarak anlamlı bir ilişki oluştuğu dikkati çekmektedir. Siyasi partilerin ittifak yapması hakkındaki görüşlerine bakıldığında, erkek seçmenlerin terör sorununu çözmek için ittifak yapıldığı $(A . O=2,42)$, $(\mathrm{t}=2,361, \mathrm{p}=\mathbf{0}, 019)$, görüşü dikkati çekmektedir. Kadın seçmenler ise cumhurbaşkanlığ 1 hükümet sisteminin partileri ittifak kurmaya yönelttiğini(A.O=3,21), (t=3,745, p=0, 000), partilerin ittifak yapmasının yeni bir siyaset modeli olduğunu $(A . O=3,19),(t=3,815, p=0,000)$, siyasi partiler arası ittifak yapılması, ittifakı oluşturan siyasi partilerin çıkarları için kurulduğunu(A.O=3,50) $(\mathrm{t}=3,983, \mathrm{p}=\mathbf{0}, 000)$ yönünde görüş belirtmişlerdir. Bununla birlikte kadın seçmenler; sosyal medyanın, ittifak içinde olan partilerin söylem, aday ve projelerini tanımalarında etkili olduğunu (A.O=3,77), $(\mathrm{t}=3,247, \mathrm{p}=\mathbf{0}, 001)$, seçim döneminde ittifakların yazılı ve görsel medyanın önemli gündemi oluşturduğunu (A.O=3,89), ( $t=4,515, p=\mathbf{0}, 000)$, seçim süreci içerisinde siyasi partilerin ittifak haberlerinin çeşitli kitle iletişim araçlarında yapılan siyasi kampanyaların siyasal tercihlerinde etkili olduğunu (A.O=3,71), $(t=2,739$, $\mathrm{p}=\mathbf{0}, 006)$, yazılı ve görsel medyanın ittifak içinde olan partilerin söylem, aday ve projelerini tanımalarında etkili olduğu (A.O=3,89), $(\mathrm{t}=3,078, \mathrm{p}=\mathbf{0}, 002)$ yönünde tespitleri ortaya konulabilir. Bu bağlamda; siyasi partilerin ittifak süreçlerini sosyal medya ve kitle iletişim araçlarının gündemde tutması, söylem ve kampanyaların takibi ve siyasal açıdan bilgilenme de etkili olarak kadın seçmenlerin tercihlerine yön verdiği yönünde görüş ortaya konulabilir. 
Tablo 22. Türkiye'de Siyasi Partilerin İttifak Yapması Hakkında Seçmenlerin Görüşleri ile Ĕ̆itim Değişkeni Arasındaki İlişkiye Yönelik Anova Testi

\begin{tabular}{|c|c|c|c|c|c|c|c|c|c|c|c|c|c|c|}
\hline \multirow[t]{2}{*}{ Eğitim } & \multicolumn{2}{|c|}{ 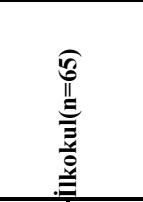 } & \multicolumn{2}{|c|}{ 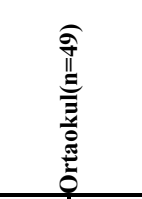 } & \multicolumn{2}{|c|}{ 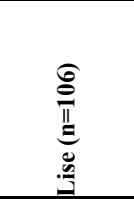 } & \multicolumn{2}{|c|}{ 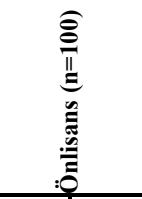 } & \multicolumn{2}{|c|}{ 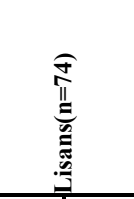 } & \multicolumn{2}{|c|}{ 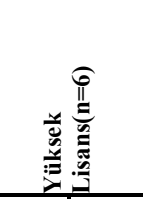 } & \multicolumn{2}{|c|}{ Anova Testi } \\
\hline & Ort. & Ss. & Ort. & Ss. & Ort. & Ss. & Ort. & Ss. & Ort. & Ss. & Ort. & Ss. & $\mathbf{F}$ & $\mathbf{p}$ \\
\hline $\begin{array}{l}\text { Siyasi partiler arası } \\
\text { ittifak yapılması oy } \\
\text { verme davranışımda } \\
\text { değişiklik yaratmıştır }\end{array}$ & 2,66 & 1,36 & 3,00 & 1,33 & 2,89 & 1,44 & 2,59 & 1,34 & 3,16 & 1,22 & 2,83 & 1,47 & 1,916 & 0,091 \\
\hline $\begin{array}{l}\text { Cumhurbaşkanlığ1 } \\
\text { Hükümet Sistemi } \\
\text { partileri ittifak kurmaya } \\
\text { yöneltmiştir }\end{array}$ & 2,96 & 1,19 & 3,04 & 1,30 & 2,96 & 1,26 & 2,78 & 1,13 & 3,04 & 1,17 & 2,83 & 1,16 & 0,544 & 0,743 \\
\hline $\begin{array}{l}\text { D1ş politikadan kaynaklı } \\
\text { sorunları çözmek için } \\
\text { ittifak kurulmuştur }\end{array}$ & 2,47 & 1,11 & 2,36 & 1,20 & 2,43 & 1,24 & 2,35 & 1,03 & 2,13 & 0,98 & 3,66 & 0,81 & 2,461 & 0,033 \\
\hline $\begin{array}{l}\text { Terör sorununu çözmek } \\
\text { için ittifak kurulmuştur }\end{array}$ & 2,38 & 1,09 & 2,18 & 1,21 & 2,36 & 1,28 & 2,41 & 1,12 & 2,06 & 1,18 & 3,16 & 1,32 & 1,579 & 0,165 \\
\hline $\begin{array}{l}\text { Partilerin ittifak yapmas1 } \\
\text { yeni bir siyaset } \\
\text { modelidir }\end{array}$ & 3,06 & 1,08 & 2,79 & 1,09 & 2,85 & 1,22 & 3,00 & 1,18 & 2,89 & 1,18 & 2,83 & 1,32 & 0,465 & 0,802 \\
\hline $\begin{array}{l}\text { Siyasi partiler arası } \\
\text { ittifak yapılmas1, ittifak1 } \\
\text { oluşturan siyasi } \\
\text { partilerin çıarları için } \\
\text { kurulmuştur }\end{array}$ & 3,15 & 1,09 & 3,24 & 1,14 & 3,23 & 1,14 & 3,17 & 1,17 & 3,32 & 1,28 & 3,00 & 1,09 & 0,247 & 0,941 \\
\hline $\begin{array}{l}\text { Sosyal medya, ittifak } \\
\text { içinde olan partilerin } \\
\text { söylem, aday ve } \\
\text { projelerini tanımamızda } \\
\text { etkili olmuştur }\end{array}$ & 3,46 & 1,07 & 3,53 & 1,08 & 3,52 & 1,13 & 3,46 & 1,06 & 3,85 & 1,05 & 3,00 & 1,26 & 1,674 & 0,140 \\
\hline $\begin{array}{l}\text { Ittifaklar siyasi partilerin } \\
\text { baraj kaygilarından } \\
\text { doğmuştur }\end{array}$ & 3,32 & 1,03 & 3,51 & 1,02 & 3,45 & 1,10 & 3,04 & 1,30 & 3,59 & 1,01 & 2,66 & 0,81 & 3,075 & 0,010 \\
\hline $\begin{array}{l}\text { Önümüzdeki siyasi } \\
\text { süreçte hiçbir partinin } \\
\text { tek başına iktidar olma } \\
\text { şansı yoktur }\end{array}$ & 3,46 & 1,11 & 3,75 & 1,21 & 3,66 & 1,09 & 3,30 & 1,20 & 3,82 & 1,06 & 2,66 & 1,03 & 3,177 & 0,008 \\
\hline $\begin{array}{l}\text { Seçim döneminde } \\
\text { ittifaklar yazılı ve görsel } \\
\text { medya açısından önemli } \\
\text { gündem olmuştur }\end{array}$ & 3,47 & 1,03 & 3,79 & 1,13 & 3,66 & 1,02 & 3,54 & 1,11 & 3,66 & 1,05 & 2,83 & 0,98 & 1,304 & 0,261 \\
\hline $\begin{array}{l}\text { Seçim süreci içerisinde } \\
\text { siyasi partilerin ittifak } \\
\text { haberleri çeşitli kitle } \\
\text { iletişim araçlarında } \\
\text { yapılan siyasi } \\
\text { kampanyalar siyasal } \\
\text { tercihimde etkili olmuştu }\end{array}$ & 3,33 & 1,09 & 3,65 & 1,25 & 3,68 & 1,08 & 3,51 & 1,16 & 3,48 & 1,18 & 2,33 & 0,81 & 2,227 & 0,051 \\
\hline
\end{tabular}

Tablo 22 incelendiğinde, Türkiye'de siyasi partilerin ittifak yapması hakkında seçmenlerin görüşleri ile eğitim değişkeni arasındaki ilişki karşılaştırıldığında istatistikî olarak anlamlı bir ilişki oluşmadığı görülmüştür. Yüksek lisans mezunu seçmenler dış politikadan kaynaklı sorunları çözmek için ittifak kurulduğu $(A . O=3,50),(t=2,461, p=0,033)$ görüşündedirler. Lisans mezunu seçmenler ittifakların siyasi partilerin baraj kaygılarından doğduğunu $(\mathrm{A} . \mathrm{O}=\mathbf{3}, \mathbf{5 9}),(\mathrm{t}=3,075, \mathrm{p}=\mathbf{0 , 0 1 0})$ ve önümüzdeki siyasi süreçte hiçbir partinin tek başına iktidar olma şansı olmadığını (A.O=3,82), $(\mathrm{t}=3,177, \mathrm{p}=\mathbf{0 , 0 0 8})$ beyan etmişlerdir. 
Tablo 23. Türkiye'de Siyasi Partilerin İttifak Yapması Hakkında Seçmenlerin Görü̈sleri ile Yaş Değişkeni Arasındaki ilişkiye Yönelik Anova Testi

\begin{tabular}{|c|c|c|c|c|c|c|c|c|c|c|c|c|}
\hline \multirow{2}{*}{ Yaş } & \multicolumn{2}{|c|}{$\begin{array}{l}\infty \\
\stackrel{\infty}{0} \\
\stackrel{\infty}{=}\end{array}$} & \multicolumn{2}{|c|}{ 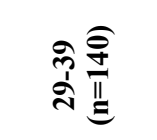 } & \multicolumn{2}{|c|}{ 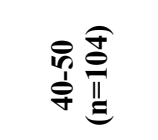 } & \multicolumn{2}{|c|}{ 它 } & \multicolumn{2}{|c|}{ 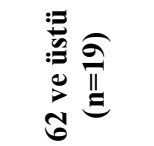 } & \multicolumn{2}{|c|}{ Anova testi } \\
\hline & Ort. & Ss. & Ort. & Ss. & Ort. & Ss. & Ort. & Ss. & Ort. & Ss. & $\mathbf{F}$ & $\mathbf{p}$ \\
\hline $\begin{array}{l}\text { Siyasi partiler arası ittifak } \\
\text { yapılması oy verme } \\
\text { davranışımda değişiklik } \\
\text { yaratmıştır }\end{array}$ & 2,73 & 1,36 & 3,06 & 1,40 & 2,85 & 1,36 & 2,44 & 1,15 & 2,36 & 1,11 & 2,320 & 0,056 \\
\hline $\begin{array}{l}\text { Cumhurbaşkanlığ } 1 \\
\text { Hükümet Sistemi partileri } \\
\text { ittifak kurmaya } \\
\text { yöneltmiştir }\end{array}$ & 2,80 & 1,21 & 3,05 & 1,22 & 2,91 & 1,21 & 3,10 & 1,23 & 2,73 & 0,87 & 0,945 & 0,438 \\
\hline $\begin{array}{l}\text { Diş politikadan kaynaklı } \\
\text { sorunları çözmek için } \\
\text { ittifak kurulmuştur }\end{array}$ & 2,50 & 1,11 & 2,30 & 1,15 & 2,35 & 1,13 & 2,20 & 1,08 & 2,52 & 1,02 & 0,710 & 0,585 \\
\hline $\begin{array}{l}\text { Terör sorununu çözmek } \\
\text { için ittifak kurulmuştur }\end{array}$ & 2,63 & 1,25 & 2,18 & 1,22 & 2,19 & 1,10 & 2,20 & 1,14 & 2,26 & 0,99 & 2,772 & 0,027 \\
\hline $\begin{array}{l}\text { Partilerin ittifak yapmas1 } \\
\text { yeni bir siyaset modelidir }\end{array}$ & 2,85 & 1,17 & 2,95 & 1,21 & 2,97 & 1,16 & 2,86 & 1,09 & 2,94 & 0,97 & 0,194 & 0,941 \\
\hline $\begin{array}{l}\text { Siyasi partiler arası ittifak } \\
\text { yapılması, ittifakı } \\
\text { oluşturan siyasi partilerin } \\
\text { çıarları için kurulmuştur }\end{array}$ & 3,15 & 1,20 & 3,25 & 1,23 & 3,38 & 0,99 & 2,86 & 1,21 & 2,94 & 1,07 & 1,589 & 0,176 \\
\hline $\begin{array}{l}\text { Sosyal medya, ittifak } \\
\text { içinde olan partilerin } \\
\text { söylem, aday ve } \\
\text { projelerini tanımamızda } \\
\text { etkili olmuştur }\end{array}$ & 3,36 & 1,16 & 3,90 & 1,01 & 3,48 & 1,06 & 3,27 & 0,99 & 2,84 & 0,83 & 7,558 & 0,000 \\
\hline $\begin{array}{l}\text { İttifaklar siyasi partilerin } \\
\text { baraj kaygilarından } \\
\text { doğmuştur }\end{array}$ & 3,16 & 1,25 & 3,62 & 1,05 & 3,35 & 1,03 & 3,17 & 1,19 & 2,63 & 0,89 & 4,989 & 0,001 \\
\hline $\begin{array}{l}\text { Önümüzdeki siyasi } \\
\text { süreçte hiçbir partinin tek } \\
\text { başına iktidar olma şansı } \\
\text { yoktur }\end{array}$ & 3,48 & 1,17 & 3,70 & 1,13 & 3,65 & 1,13 & 3,44 & 1,18 & 2,73 & 0,87 & 3,449 & 0,009 \\
\hline $\begin{array}{l}\text { Seçim döneminde } \\
\text { ittifaklar yazılı ve görsel } \\
\text { medya açısından önemli } \\
\text { gündem olmuştur }\end{array}$ & 3,50 & 1,19 & 3,80 & 0,98 & 3,60 & 1,00 & 3,41 & 1,08 & 3,00 & 0,94 & 3,345 & 0,010 \\
\hline $\begin{array}{l}\text { Seçim süreci içerisinde } \\
\text { siyasi partilerin ittifak }\end{array}$ & 3,50 & 1,27 & 3,64 & 1,11 & 3,54 & 1,10 & 3,27 & 1,06 & 3,00 & 0,94 & 1,719 & 0,145 \\
\hline
\end{tabular}


Tablo 23 incelendiğinde Türkiye'de siyasi partilerin ittifak yapması hakkında seçmenlerin görüşleri ile yaş değişkeni arasındaki ilişkiyi karşılaştırdığında istatistikî olarak anlamlı bir ilişki oluştuğu görülmüştür. 18-28 yaş grubu seçmenler terör sorununu çözmek için ittifak yapıldığ (A.O=2,63), ( $\mathrm{t}=2,772, \mathrm{p}=\mathbf{0}, 027)$ görüşündedirler. 29-39 yaş grubu seçmenler sosyal medyanın, ittifak içinde olan partilerin söylem, aday ve projelerinin tanınmasında etkili olduğunu $(\mathrm{A} . \mathrm{O}=\mathbf{3 , 9 0}),(\mathrm{t}=7,558, \mathrm{p}=\mathbf{0 , 0 0 0})$, ittifakların siyasi partilerin baraj kaygılarından doğduğunu (A.O=3,62), ( $\mathrm{t}=4,989, \mathrm{p}=\mathbf{0 , 0 0 1})$, önümüzdeki siyasi süreçte hiçbir partinin tek başına iktidar olma şansı olmadığını (A.O=3,70), $(t=3,449, p=0,009)$; seçim döneminde ittifaklar yazılı ve görsel medyanın önemli gündemini oluşturduğunu ( $\mathrm{A} . \mathrm{O}=\mathbf{3 , 8 0}),(\mathrm{t}=3,345, \mathrm{p}=\mathbf{0 , 0 1 0})$ ve yazılı ve görsel medyanın ittifak içinde olan partilerin söylem, aday ve projelerini tanınmasında etkili olduğu $(\mathrm{A} . \mathrm{O}=\mathbf{3 , 8 5}),(\mathrm{t}=3,543, \mathrm{p}=\mathbf{0 , 0 0 7})$ görüşlerini beyan etmişlerdir. Bu bağlamda yaş grupları ile Türkiye'de siyasi partilerin ittifak yapması hakkında seçmenlerin görüşleri arasında farklılıkları ortaya koymak için Anova testi yapılmıştır. Bu test sonucunda hangi yaş gruplarında farklılık olduğunu ortaya koymak amacıyla Multiple Comparisons testi yapılmıştır. $\mathrm{Bu}$ test sonucunda, sosyal medya, ittifak, içinde olan partilerin söylem, aday ve projelerini tanımalarında etkili olmuştur önermesine verilen cevaplar incelendiğinde; 18-28 ile 29-39 yaş grupları $(\mathrm{p}<0.003)$ arasında ve 29-39 ile 62 ve üstü yaş grupları $(\mathrm{p}<0.002)$ arasında anlamlı bir farklılık oluştuğu görülmüştür. Bu ifadeyi en fazla anlamlı bulan yaş grubu 29-39 ile 62 ve üstü yaş grubunun arasında farklılık yarattığını söylenilmesi mümkündür. İttifakların siyasi partilerin baraj kaygılarından doğduğu önermesi noktasında 29-39 ile 62 ve üstü yaş grupları $(\mathrm{p}<0.011)$ arasında anlamlı bir farklılık oluşmaktadır. Diğer yaş grupları arasında farklılık oluşmamaktadır. Önümüzdeki siyasi süreçte hiçbir partinin tek başına iktidar olma şansı olmadığı önermesi noktasında 29-39 ile 62 ve üstü yaş grupları $(\mathrm{p}<0.017)$ arasında anlamlı bir farklılık oluştuğu dikkati çekmektedir. Yazılı ve görsel medya ittifak içinde olan partilerin söylem, aday ve projelerini tanınmasında etkili olduğu önermesine verilen cevaplar incelendiğinde, 29-39 ile 62 ve üstü yaş grupları ( $\mathrm{p}<0.028)$ arasında anlamlı bir farklılık oluştuğu görülmektedir. Bu bağlamda anlamlı farklılaşmanın olduğu 29-39 ile 62 ve üstü yaş gruplarıdır. $\mathrm{Bu}$ yaş gruplarının en fazla önem verdiği hususlar sosyal medya, ittifak içinde olan partilerin söylem, aday ve projelerini tanımalarında etkili olduğu görüşleridir. 
Tablo 24. Türkiye'de Siyasi Partilerin İttifak Yapması Hakkında Seçmenlerin Görü̈sleri ile Gelir Değişkeni Arasındaki İlişkiye Yönelik Anova Testi

\begin{tabular}{|c|c|c|c|c|c|c|c|c|c|c|c|c|c|c|}
\hline \multirow[t]{2}{*}{ Gelir } & \multicolumn{2}{|c|}{ 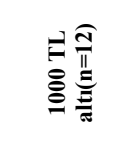 } & \multicolumn{2}{|c|}{ 总䧽 } & \multicolumn{2}{|c|}{ 总 } & \multicolumn{2}{|c|}{ 总 } & \multicolumn{2}{|c|}{ 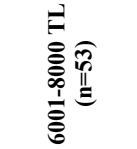 } & \multicolumn{2}{|l|}{ 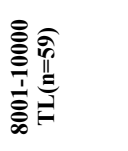 } & \multicolumn{2}{|c|}{ Anova Testi } \\
\hline & Ort. & Ss. & Ort. & Ort. & Ort. & Ss. & Ort. & Ss. & Ort. & Ort. & Ort. & Ss. & $\mathbf{F}$ & $\mathbf{P}$ \\
\hline $\begin{array}{l}\text { Siyasi partiler arası } \\
\text { ittifak yapılması oy } \\
\text { verme davranışımda } \\
\text { değişiklik yaratmıştır } \\
\end{array}$ & 3,00 & 1,76 & 2,11 & 1,44 & 2,40 & 1,55 & 2,50 & 1,44 & 2,09 & 1,41 & 2,28 & 1,37 & 1,258 & 0,282 \\
\hline $\begin{array}{l}\text { Cumhurbaşkanlığı } \\
\text { Hükümet Sistemi } \\
\text { partileri ittifak kurmaya } \\
\text { yöneltmiştir }\end{array}$ & 2,78 & 1,87 & 2,03 & 1,48 & 2,35 & 1,56 & 2,37 & 1,55 & 2,06 & 1,37 & 2,26 & 1,37 & 2,481 & 0,031 \\
\hline $\begin{array}{l}\text { Diş politikadan kaynaklı } \\
\text { sorunları çözmek için } \\
\text { ittifak kurulmuștur }\end{array}$ & 2,89 & 1,79 & 2,12 & 1,49 & 2,36 & 1,57 & 2,41 & 1,52 & 2,02 & 1,38 & 2,24 & 1,38 & 4,030 & 0,001 \\
\hline $\begin{array}{l}\text { Terör sorununu çözmek } \\
\text { için ittifak kurulmuştur }\end{array}$ & 2,84 & 1,83 & 2,09 & 1,45 & 2,33 & 1,59 & 2,35 & 1,56 & 2,04 & 1,38 & 2,21 & 1,42 & 4,905 & 0,000 \\
\hline $\begin{array}{l}\text { Partilerin ittifak yapması } \\
\text { yeni bir siyaset } \\
\text { modelidir }\end{array}$ & 2,89 & 1,79 & 2,19 & 1,49 & 2,37 & 1,56 & 2,41 & 1,49 & 2,25 & 1,27 & 2,26 & 1,39 & 2,051 & 0,071 \\
\hline $\begin{array}{l}\text { Siyasi partiler arası } \\
\text { ittifak yapılması, ittifakı } \\
\text { oluşturan siyasi } \\
\text { partilerin çıkarları için } \\
\text { kurulmuştur }\end{array}$ & 2,94 & 1,74 & 2,17 & 1,45 & 2,41 & 1,59 & 2,41 & 1,52 & 2,06 & 1,51 & 2,14 & 1,42 &, 348 & 0,883 \\
\hline $\begin{array}{l}\text { Sosyal medya, ittifak } \\
\text { içinde olan partilerin } \\
\text { söylem, aday ve } \\
\text { projelerini tanımamızda } \\
\text { etkili olmuştur }\end{array}$ & 2,89 & 1,79 & 2,01 & 1,47 & 2,57 & 1,52 & 2,39 & 1,54 & 2,15 & 1,32 & 2,14 & 1,44 & 2,363 & 0,039 \\
\hline $\begin{array}{l}\text { Ittifaklar siyasi partilerin } \\
\text { baraj kaygılarından } \\
\text { doğmuştur }\end{array}$ & 3,15 & 1,53 & 2,06 & 1,45 & 2,40 & 1,55 & 2,47 & 1,49 & 2,06 & 1,46 & 2,18 & 1,43 & 2,450 & 0,033 \\
\hline $\begin{array}{l}\text { Önümüzdeki siyasi } \\
\text { süreçte hiçbir partinin } \\
\text { tek başına iktidar olma } \\
\text { şansı yoktur }\end{array}$ & 3,10 & 1,59 & 2,09 & 1,45 & 2,37 & 1,53 & 2,36 & 1,55 & 2,25 & 1,38 & 2,14 & 1,41 & 2,179 & 0,056 \\
\hline $\begin{array}{l}\text { Seçim döneminde } \\
\text { ittifaklar yazılı ve görsel } \\
\text { medya açısından önemli } \\
\text { gündem olmuştur }\end{array}$ & 3,00 & 1,76 & 2,07 & 1,46 & 2,30 & 1,56 & 2,36 & 1,53 & 2,09 & 1,41 & 2,25 & 1,42 & ,997 & 0,419 \\
\hline $\begin{array}{l}\text { Seçim süreci içerisinde } \\
\text { siyasi partilerin ittifak } \\
\text { haberleri çeşitli kitle } \\
\text { iletişim araçlarında } \\
\text { yapılan siyasi } \\
\text { kampanyalar siyasal } \\
\text { tercihimde etkili } \\
\text { olmuştu }\end{array}$ & 2,89 & 1,79 & 2,01 & 1,48 & 2,29 & 1,56 & 2,35 & 1,56 & 2,02 & 1,38 & 2,24 & 1,45 & 1,539 & 0,177 \\
\hline $\begin{array}{l}\text { Siyasi partiler arası } \\
\text { ittifakların devam etmesi }\end{array}$ & 3,10 & 1,59 & 2,01 & 1,47 & 2,28 & 1,59 & 2,43 & 1,44 & 2,18 & 1,35 & 2,19 & 1,40 & 1,436 & 0,210 \\
\hline
\end{tabular}

Tablo 24 incelendiğinde Türkiye'de siyasi partilerin ittifak yapması hakkında seçmenlerin görüşleri ile yaş değişkeni arasındaki ilişki karşılaştırıldığında istatistikî olarak anlamlı bir ilişki oluşmadığ 1 tespit edilmiştir. 1000 TL altı gelir grubu seçmenler, Cumhurbaşkanlığı Hükümet Sisteminin partileri ittifak kurmaya yönelttiğini(A.O=2,78), $(t=2,481, \quad p=\mathbf{0 , 0 3 1}), \quad$ Dış politikadan kaynaklı sorunları çözmek için ittifak kurulduğunu(A.O=2,89), $(\mathrm{t}=4,030, \mathrm{p}=\mathbf{0 , 0 0 1})$, terör sorununu çözmek için ittifak yapıldığ $(\mathrm{A} . \mathrm{O}=\mathbf{2 , 8 4}),(\mathrm{t}=4,905, \mathrm{p}=\mathbf{0 , 0 0 0})$, ittifakların siyasi partilerin baraj kaygılarından doğduğu $(A . O=3,15),(t=2,450, p=\mathbf{0 , 0 3 3})$ görüşündedir. $B u$ 
bağlamda yaş grupları ile Türkiye'de siyasi partilerin ittifak yapması hakkında seçmenlerin görüşleri arasında farklılıkları ortaya koymak için Anova testi yapılmıştır. Bu test sonucunda hangi yaş gruplarında farklılık olduğunu ortaya koymak amacıyla Multiple Comparisons testi yapılmıştır. Bu test sonucunda dış politikadan kaynaklı sorunları çözmek için ittifak kurulduğu önermesine verilen cevaplar incelendiğinde, 1000 TL altı ve 2001-4000 TL gelir grupları $(\mathrm{p}<0.026)$ arasında anlamlı bir farklılık oluştuğu dikkati çekmektedir. Terör sorununu çözmek için ittifak yapıldığı ifadesine verilen cevaplar incelendiğinde, 1000 TL altı ve 2001-4000 TL gelir grupları $(\mathrm{p}<0.003)$ arasında anlamlı bir farklılık oluştuğu görülmüştür.

\section{Sonuç ve Değerlendirme}

16 Nisan 2017 yılında yapılan referandumun sonucu olarak anayasa değişikliği gerçekleştirilmiştir. Anayasal düzenleme ile birlikte Türkiye'de Cumhurbaşkanlığı Hükümet Sistemine geçilmiş ve siyasi partiler arası ittifaka zemin hazırlanmıştır. Hükümet sistemi değişikliği ile birlikte, seçim kanununda bazı düzenlemelere gidilmiştir. Hem Cumhurbaşkanlığı, hem genel seçimlerde hem de yerel seçimlerde partiler arası ittifaka imkân sağlanmıştır. Seçim kanununda yapılan düzenleme ile siyasi partilerin ortak aday çıkarabilecekleri ve ittifak ortak adayına yönelik bilgilerin seçim pusulalarına dâhil edileceği belirtilmiştir. 24 Haziran 2018 Cumhurbaşkanlığı seçimlerinde, seçim ittifakı partiler arasında uygulanmıştır. 31 Mart 2019 yılında gerçekleştirilen Mahalli İdare Seçimlerinde de partiler arası ittifak uygulamasına gidilmiş ve partiler bazı seçim bölgelerinde ortak aday çıkararak ittifak gerçekleştirmişlerdir. Bununla birlikte, bazı partilerin adayları, kendi partilerinden seçime girmek yerine başka partilerden aday gösterilmiş ve örtülü bir ittifak gerçekleştirilmiştir.

Bu minvalden hareketle gerçekleştirilen çalışmada, seçim sisteminde bu değişiklikler ve ittifak uygulamalarının halka yansımasının nasıl olduğunu görmek amacıyla Karaman il merkezinde gerçekleştirilen araştırma kapsamında seçmenlerin siyasi partiler arasında uygulanan seçim ittifaklarına yönelik algılarının ölçülmesi sonucunda elde edilen veriler ve bulgular dikkate alındığında ortaya konulacak tespitler şu şekilde sıralanabilir:

- Araştırma kapsamında cevabı aranan ilk soru, "siyasi partiler arası seçim ittifaklarının yapılması seçmenlerin oy verme davranışlarında değişikliğe yol açmış mıdır?" şeklindedir. Araştırmaya dâhil edilen seçmenlerin yaklaşık üçte birinin siyasi partiler arası ittifak yapılmasının, oy verme davranışlarında değişiklik yaratmadığı görüşünü ortaya koymuştur. Burada dikkati çeken bir diğer husus, katılımcıların, beşte birinin siyasi partiler arası ittifak yapılması sebebiyle hem kendi partisinin adayını desteklediğini ve hem de ittifak adayına oy verdiğini belirtmiş olmasıdır

- Araştırma kapsamında cevabı aranacak ikinci soru, "siyasi partiler arası seçim ittifaklarının yapılması seçmenlerin oy verdiği parti için faydalı olmuş mudur?” şeklindedir. Katılımcıların yaklaşık üçte birinin partiler arası ittifak uygulamasının oy verdiği parti için faydalı olduğunu düşündügü yönünde görüş birliğinde olduğu dikkati çekmiştir. Bununla birlikte, seçmenlerin büyük bir kısmının $(\% 41,1)$ siyasi partiler arası ittifakın fayda noktasında bir kararsızlık içinde olduğu ve siyasi parti ittifakları konusunda yeterince ikna edilemedikleri yönünde ifade edilebilir.

- Araştırmada cevabı aranan üçüncü soru "seçmenlerin siyasi partiler arası yapılan seçim ittifakı uygulamasının içeriği hakkında ne düzeyde bilgi sahibi olduğudur?". Seçmenlerin yarısının "hem siyasi partilerin seçim ittifakından hem de ittifakların hangi 
partiler arasında gerçekleştirildiği” konusunda bilgi sahibi olmadığı hususu araştırmada altı çizilmesi gereken sonuçlardan birisidir.

- Araştırmada cevabı aranan dördüncü soru, "siyasi partilerin ittifak hakkında siyasal bilgilenmede kitle iletişim araçları etkili oldu mu?" beşinci soru ise "siyasi partilerin ittifakı hakkında siyasal bilgilenme seçmenlerin oy vermelerinde etkili oldu mu?" şeklindedir. Yazılı ve görsel medya ile birlikte sosyal medyanın da ittifak içinde olan partilerin söylemleri, aday ve projelerini tanıma noktasında seçmenler üzerinde etkili olduğu görülmektedir. Bununla birlikte, seçim döneminde ittifakların yazılı ve görsel medya açısından önemli gündem maddesi olarak değerlendirildiği araştırmaya katılan seçmenler tarafindan dile getirilmiştir. Araştırmaya katılan seçmenlerin büyük bir kısmı, "seçim süreci içerisinde siyasi partilerin ittifak haberleri çeşitli kitle iletişim araçlarında yapılan siyasi kampanyalar siyasal tercihimde etkili olmuştur” önermesine katıldığını beyan etmiştir.

- "Siyasi partiler arası ittifak yapılması parti bağlılı̆̆ına değişiklik yaratmış mıdır?" şeklindeki araştırmanın altıncı sorusu incelendiğinde, katılımcıların yaş grupları üzerinden bir karşılaştırma yapmakta yarar olduğu söylenilebilir.

- Orta yaş grubu seçmenler arasında, siyasi partiler arası ittifak yapılması sebebiyle tepki koyarak başka partilere/başka adaylara oy verdikleri görüşü daha fazla hâkim iken; 62 ve üstü yaş grubu seçmenlerin görüşleri ise, siyasi partiler arası ittifak yapılması sebebiyle sadece kendi parti adayını desteklediği ve ittifak adayına oy vermediği ve siyasi partiler arası ittifak yapılması sebebiyle, ittifak partilerin hiçbirine oy vermediği şeklinde farklı cevaplarla şekillenmiştir. Diğer taraftan genç seçmenler arasında yaklaşık üçte birlik kısmının siyasi partiler arası ittifak yapılmasının, oy verme davranışlarında değişiklik yaratmadığı görüşü ortaya çıkmıştır. Bu konuda elde edilen bir diğer bulgu siyasi partiler arası ittifak yapılmasının orta gelirli seçmenlerin oy verme davranışlarında yeterince değişiklik yaratmadığıdır.

Bu sorular dışında elde edilen diğer bulgulara bakıldığında şu hususlar dikkati çekmektedir:

- Katılımcıların yaklaşık üçte biri $(\% 38,2)$ Cumhurbaşkanlığı Hükümet Sistemi sonucunda partilerin ittifak yapmalarının zorunluluk haline geldiğini beyan etmesi dikkati çeken önemli bir husustur.

- Seçimlerde oy verme davranışı etkileyen faktörler incelendiğinde, seçmenleri en çok etkileyen faktörün ülke geleceğinde etkili olabileceği için oy kullandığı düşüncesidir. Seçmenlerin üçte ikisi bu yönde görüş beyanında bulunmuştur. Kişisel çıkar için oy kullanırım diyenlerin oranın düşük düzeyde (\% 8) kalması seçmenlerin bilinç düzeyinin yüksekliğini göstermektedir.

- Siyasi partiler arası ittifak uygulamaları konusunda farkındalık düzeyleri eğitim değişkeni üzerinden incelendiğinde; eğitim düzeyi yükseldikçe, farkındalık ve bilinç düzeyinin de yükseldiği, eğitim düzeyi yüksek katılımcıların siyasi partilerin ittifakları ve içeriği konusunda daha fazla bilgi sahibi oldukları altı çizilmesi gereken bir diğer sonuçtur.

- 40-50 yaş grubu seçmenlerin hem siyasi partilerin seçim ittifakından haberdar oldukları ve hem de ittifakların hangi partiler arasında gerçekleştirildiği konusunda oldukça bilgi sahibi oldukları (\% 66,3) görülmektedir. Bu bağlamda orta yaş seçmenlerin siyasi konulara olan ilgilerinin daha yüksek olduğu ve siyasi gündemi takip ettikleri yönünde çıkarımda bulunulabilir.

- Seçmenlerin yaklaşı yarısı bir siyasi partiye oy verirken önemli gördükleri unsurlar içerisinde partinin projeleri olduğunu beyan etmişlerdir. Seçmenler için diğer önemli unsurlar sırasıyla, parti adayları, parti ideolojisi, parti liderinin imajı ve parti tüzügüüdür. 
Yüksek lisans mezunu olan katılımcılar için partinin ideolojisi ve parti projeleri etkili olarak değerlendirirken; lisans mezunları için parti tüzügü ve parti programının önemli olduğunu söylenilebilir. Yüksek lisans mezunu katılımcıların üçte ikisinin (\% 66,7) parti projelerini en önemli unsur olarak gördüklerini söylemeleri dikkati çeken bir husus olarak değerlendirilebilir. 18-28 yaş grubu seçmenlerin yarısının oy vermelerinde en önemli unsurun parti projelerinin olduğu yönünde çıkarımda bulunulabilir. Bu yönüyle düşünüldüğünde, gençlerin oy verme davranışı noktasında farkındalık düzeyinin yüksek olduğu söylenilebilir.

\section{Kaynakça}

1 Nolu Cumhurbaşkanlığı Kararnamesi. (Temmuz 10, 2018). Resmî Gazete, (Say1:30474), http://www.mevzuat.gov.tr/MevzuatMetin/19.5.1.pdf, (Erişim Tarihi: 20.12.2019).

5678 Sayılı Türkiye Cumhuriyeti Anayasasında Değişiklik Yapılmasına Dair Kanun (31 Mayıs 2007), https://www.tbmm.gov.tr/kanunlar/k5678.html, (Erişim Tarihi: 20.12.2019).

6771 sayılı Türkiye Cumhuriyeti Anayasasında Değişiklik Yapılmasına Dair Kanun (11 Şubat 2017), Resmi Gazete (Sayl: 29976). https://www.resmigazete.gov.tr/eskiler/2017/02/20170211-1.htm, (Erişim Tarihi: 20.12.2019).

7102 sayılı "Seçimlerin Temel Hükümleri ve Seçmen Kütükleri Hakkında Kanun ile Bazı Kanunlarda Değişiklik Yapılmasına Dair Kanun” (13 Mart 2018), Resmi Gazete (Sayı: 30362), https://www.resmigazete.gov.tr/eskiler/2018/03/20180316-28.htm, (Erişim Tarihi: 20.12.2019).

Akman, E. (2019). Cumhurbaşkanlığı hükümet sisteminde politika aktörleri, Paradoks Dergisi, 15(1), 35-54.

Altunışık, R., Coşkun, R. \& Yıldırım, E. (2005), Sosyal bilimlerde araştırma yöntemleri: SPSS uygulamalı, (4. baskı), Sakarya: Sakarya.

Büyüköztürk, Ş., Kılıç Çakmak E., Akgün, Ö.E., Karadeniz, Ş. \& Demirel, F. (2012). Bilimsel araştırma yöntemleri, (11. baskı), Ankara: Pegem Akademi.

Gözler, K. (2015). Türk anayasa hukukuna giriş, Bursa: Ekin.

Gözler, K. (2016). Anayasa hukukuna giriş: Genel esaslar ve Türk anayasa hukuku, Bursa: Ekin.

Karaman Valiliği (2019), Karaman 2018 Yılı Nüfus Sayımı Sonuçları, http://www.karaman.gov.tr/nufus, (Erişim Tarihi: 20.12.2019).

Karaman Yerel Seçim Sonuçları, https://secim.haberler.com/2019/yerel-secimler/karamansecim-sonuclari/, (Erişim Tarihi: 20.12.2019).

Montesquieu (2017). Kanunlarının ruhu üzerine. Günen Berna (Çev.), Ankara: Türkiye İş Bankası.

Özdamar, K. (1999). Paket programlar ile istatistiksel veri analizi, Eskişehir: Kaan Kitabevi.

Türkiye Cumhuriyet Anayasası, https://www.mevzuat.gov.tr/MevzuatMetin/1.5.2709.pdf, (Erişim Tarihi: 20.12.2019).

Usta, S. \& Bilgiç E. (2017). Hemşehrilik bilinci ve kent konseyleri: Karaman ilinde bir araştırma, Süleyman Demirel Üniversitesi Sosyal Bilimler Enstitüsü Dergisi 1(26), 223-252. 